\title{
The palaeoecology of a high status Icelandic farm
}

\author{
Guðrún Sveinbjarnardóttir, Egill Erlendsson, Kim Vickers, Tom H. McGovern, \\ Karen B. Milek, Kevin J. Edwards, Ian A. Simpson and Gordon Cook
}

\begin{abstract}
Written sources indicate that the farm of Reykholt in Borgarfjörður, Iceland was built on the land of the original settlement farm, and that it had acquired the primary status in the valley by the early 12th century. Archaeological evidence suggests that the farm together with a church may have been established as early as ca. 1000 AD, which is when Christianity was adopted in Iceland. The site became one of the country's major ecclesiastical centres, growing in wealth and stature, not least during the occupancy of the writer and chieftain Snorri Sturluson in the first half of the 13th century. Long-term excavations included a palaeoenvironmental sampling programme aimed at the investigation of the economy and environment of the farm. This paper focuses upon the results of the palaeoecological analysis and places them into the historical context of the farm.
\end{abstract}

Keywords: Iceland, Viking Age, post-medieval, settlement, economy, environment

\section{Introduction}

Reykholt in Borgarfjörður is among the most important historical sites in Iceland which was first settled by the Norse in the 9th century. It was a major ecclesiastical and political centre in the medieval period and although not mentioned in Landnámabók (The Book of Settlements) (Benediktsson 1968), a list of settlements that in the 12th and 13th centuries AD, when it was compiled, were regarded as the major pioneer farms in Iceland, it must have been established by an important family soon after the area was first settled. This is inferred from late medieval written sources and by ${ }^{14} \mathrm{C}$ and archaeological evidence, which suggests that a farm was established at the site, perhaps with a church, soon after the adoption of Christianity in $c$. AD 1000. The earliest

\footnotetext{
Guðrún Sveinbjarnardóttir (corresponding author), Institute of Archaeology, University College London, 31-4 Gordon Square, London WC1H OPY, UK; email: gudrun.s@ucl.ac.uk; Egill Erlendsson and Kevin Edwards, Department of Geography and Environment and Northern Studies Centre, University of Aberdeen, Aberdeen AB24 3UF, UK; Kim Vickers, Department of Archaeology, University of Sheffield, Northgate House, West Street, Sheffield S1 4ET, UK; Tom McGovern, Anthropology Department, Hunter College CUNY, 695 Park Avenue, New York City 10021, New York; Karen Milek, Department of Archaeology, University of Aberdeen, Aberdeen AB24 3UF, UK; Ian Simpson, School of Biological and Environmental Sciences, University of Stirling, Stirling FK9 4LA, Scotland, UK; Gordon Cook, SUERC Radiocarbon Dating Laboratory, Scottish Universities Environmental Research Centre, Scottish Enterprise Technology Park, East Kilbride G75 OQF, UK.

Received January 2007; revised manuscript accepted March 2007
}

churches in Iceland were founded by individual farmers and given property by them. The farmer who built the first church at Reykholt must therefore have been of reasonable means (Sveinbjarnardóttir in press). The stature and wealth of Reykholt reached a peak during the tenure of the writer and chieftain Snorri Sturluson whose domain, by the time he was assassinated in 1241, extended over much of western Iceland.

\section{The physical setting}

Reykholt is an inland farm, placed in the middle of a prosperous valley, Reykholtsdalur, well suited for farming, about $25 \mathrm{~km}$ from the sea (Fig. 1). This is one of several near-parallel valleys running inland from the lowland area of Borgarfjörður and orientated roughly east-west with the more extensive lowland areas in the western end. The valley is flanked by a series of long hills averaging about $270 \mathrm{~m}$ a.s.l. in height, with the most fertile land lying closest to the river. The soils become thinner and less productive further inland and Reykholt lies in the zone where differentiation of land quality becomes apparent, at the junction of several formerly important travel routes. Much of Reykholt's land holding consists of gentle south-facing slopes which enjoy the most extensive exposure to sun in the valley. Since there is no direct access from the valley to mountain 


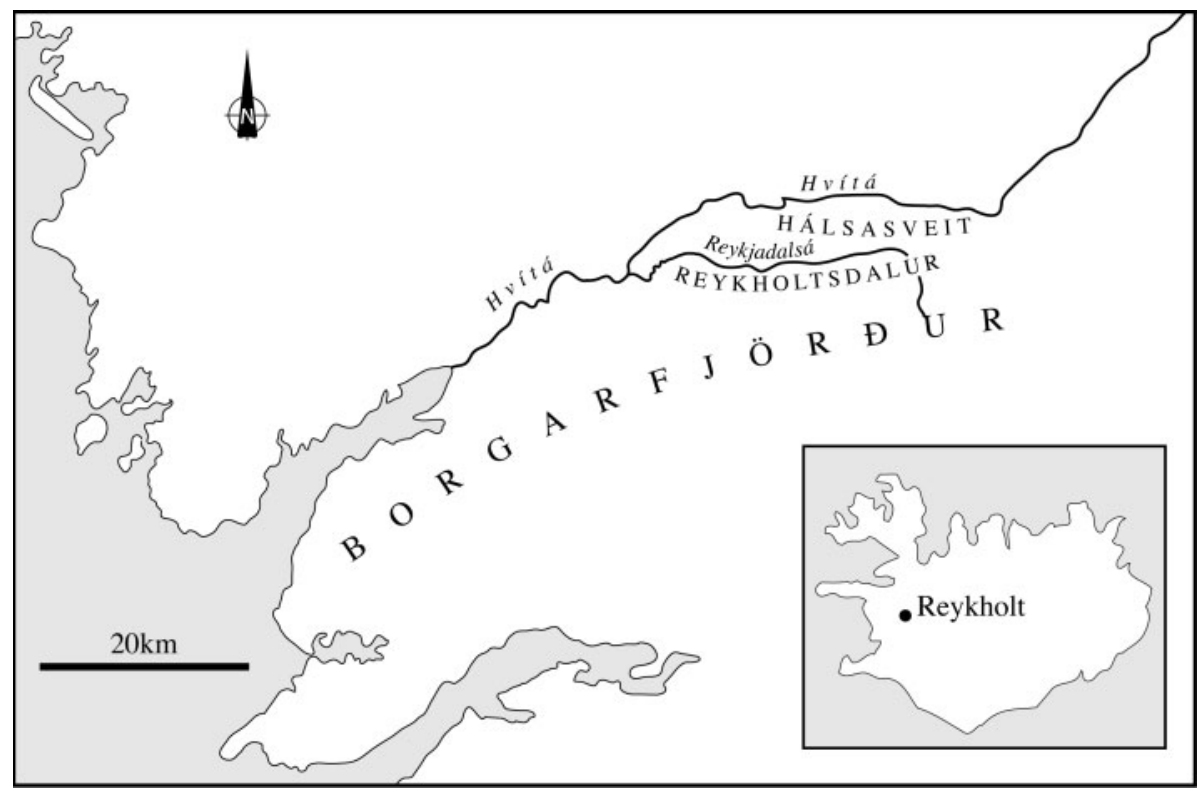

Figure 1 Location of Reykholt and Reykholtsdalur

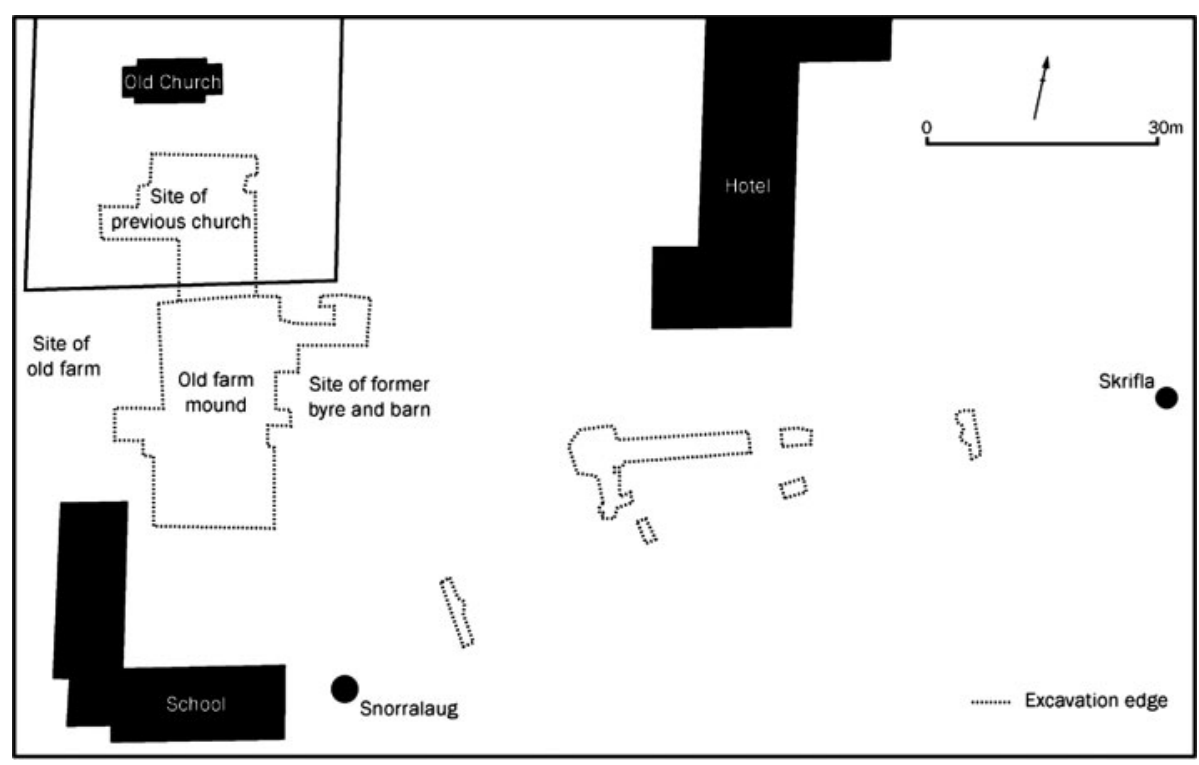

Figure 2 Plan of the Reykholt site

pasture, extra grazing and other resources were sought further afield.

\section{The archaeological investigations}

The Scottish 'missionary' Ebenezer Henderson (1818) noted the remains of fortifications when he visited Reykholt in 1814, an interpretation most probably influenced by accounts in Sturlunga saga (Jóhannesson et al. 1946, 456), and a 'stone coffin' was discovered in the cemetery in 1842 (Grímsdóttir and Ingimundardóttir 2005, 297). This was followed by a spate of finds during modern building activities, beginning with the erection of a school in 1929, only some of which were properly investigated (Sveinbjarnardóttir 2004). Systematic archaeological excavations at the farm site were conducted from
1987-9 and were resumed in 1997. Between 2003 and 2007 excavation concentrated on the remains of the church.

There is no longer a farm at Reykholt and the old farm mound is located among more recent buildings (Fig. 2) on a knoll in the middle of the valley, on land sloping gently southwards to the warm pool, Snorralaug. The nearby hot spring, Skrifla, provides the pool with water via stone-built conduits. It lies higher than the pool so that the water flows to it easily, but is lower than the farm, which it seems to have provided with steam. By the time of the modern excavations, the farm mound had been levelled and all buildings were removed. Twentieth-century building activity had destroyed parts of the farm and truncated the easternmost part of the mound. 
The excavation area covered $c .712 \mathrm{sq} \mathrm{m}$. The depth of cultural deposits found at the site varied, the maximum being around $1.25 \mathrm{~m}$. One phase had been built on top of another, and since the buildings were largely made of stone, earth and turf, a mound was gradually created. A description of the site from 1884 suggests that in the area where the excavation took place, there were many outbuildings, including a storage house, stable, byre and enclosed hay-storage area, and that these structures lay on an elevated area (Vigfússon 1885, 115-16), presumably the underlying farm mound.

The first building phase encountered during the excavation belonged to a passageway farmhouse (Fig. 3), which was relocated in 1833 (Vigfússon 1885). It was built on top of several earlier occupation phases, to which it had caused serious damage. Only two house-foundations of medieval date, structures 10/11 and 12 (Fig. 4), filled with waste material after they went out of use, were well preserved. Structure $10 / 11$ is interpreted as a foundation or cellar. The floor surface in structure 12 was covered with flagstones, and had a stone-built conduit running into it, which was partly overlain by a midden deposit [577]; it has been tentatively interpreted as a bathhouse (Sveinbjarnardóttir 2005).

A palaeoenvironmental sampling programme formed part of the excavation strategy, with sampling concentrated on floors and enclosed areas. During the initial excavation campaign, samples were taken from the floor layers of the passageway farmhouse, dated on the basis of artefacts and written sources to between the 17th and 19th centuries; these were analysed by Buckland et al. (1992) and Zutter (2000), and the results are presented here in summary form. The other samples discussed in this paper were taken during the second campaign that started in 1997 and come from context 577, belonging to the medieval phase of the farm, and from a fireplace [99] belonging to the earliest occupation phase (Fig. 4). Micromorphological analysis was carried out on samples from context 577 and from structure 10 . The choice of sample locations, which represent the first and last phases of occupation, was dictated by the availability of suitable material. The following discussion centres on the results of the analyses and the evidence they provide on the activity, economy and environment of the farm during its occupation. The multidisciplinary approach provided an important opportunity to make a holistic assessment of these issues.

\section{The environmental investigations: (1) the post- medieval passageway farmhouse}

The remains of the farmhouse lay beneath a 20 $70 \mathrm{~cm}$ thick fill, created as a result of levelling. The structural remains consisted of a central passageway with rooms to either side (Fig. 3), a typical layout for farmhouses in Iceland from the later medieval period until the early 20 th century. Samples were taken from floors in rooms 1, 2, 3 and 5, and in the passageway (Buckland et al. 1992; Zutter 2000).

Insect and plant-remains from the floor-layer overlying the flagstones in the passageway indicated that peat and hay had been spread over it. There was also evidence of stored grain within the complex in the form of the grain beetles Sitophilus granarius (L.) and Oryzaephilus surinamensis (L.). The four rooms leading off the passage that were investigated, probably represent the living room (1), hall (2), a kitchen (3), and a small workroom (5).

Two floor layers were encountered in room 1, one on top of the other, with turf separating them in the centre of the room, perhaps a measure taken to level a sinking floor. This room was built on top of structure 10/11 which had been filled with rubbish after it went out of use. The beetle fauna from the upper floor layer again indicated that hay and peat had been spread over the floor.

Across the passageway, in room 2, two floor layers, separated by a fill, were encountered. Insect analysis showed that the upper floor contained a similar assemblage to that found in room 1 . The lower layer was very organic and contained, among other objects, a quantity of fabric remnants, textile implements and pottery fragments of Martincamp type, dated to the 16th century (Sveinbjarnardóttir 1996, 97). This layer is believed to belong to activity pre-dating room 2 . The ectoparasites Damalinia ovis (L.) (sheep louse), Melophagus ovinus (L.) (sheep ked) and the human louse Pediculus humanus (L.) were found. The presence of sheep ectoparasites has been interpreted as evidence for wool processing (Buckland and Perry 1989) and this is supported by the concentration of wool processing tools recovered. This is compatible with the historical record of what took place in a hall, the main activity area within an Icelandic farm house of the post medieval period.

Compared to the layout of farms known elsewhere in Iceland, there could have been another small daily workroom in area 5 (Ágústsson 1987, fig. 31, 272). Two floor layers were encountered, the lower of which pre-dates the room. The upper layer, which is contemporary with the rest of the farm as seen on 


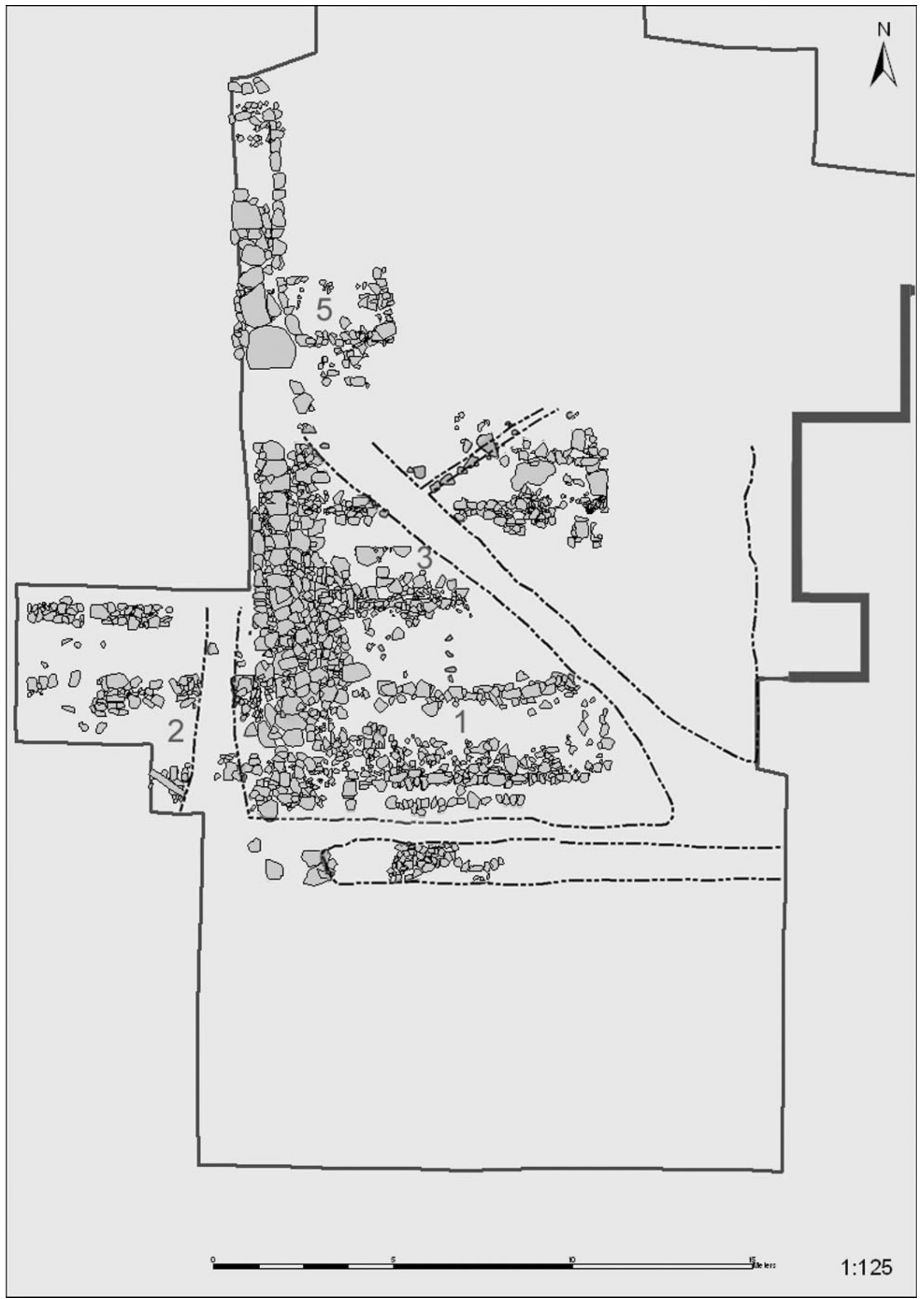

Figure 3 Site plan of the post-medieval passageway farm 


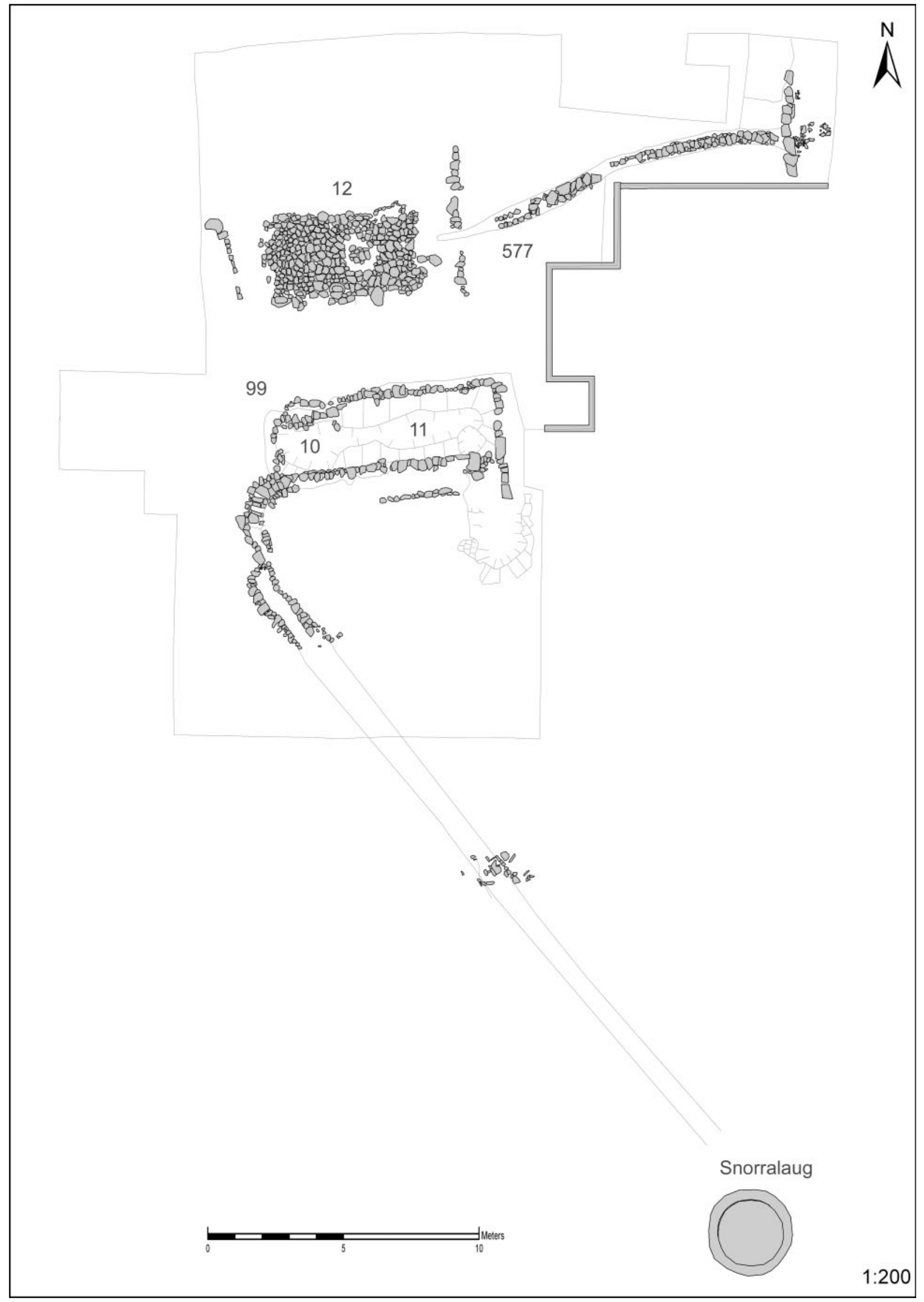

Figure 4 Site plan of medieval buildings 
Figure 3, contained large numbers of human and sheep ectoparasites. Wool fibres were also recovered. Traditionally, before wool was processed it was cleaned by soaking it in urine and then rinsed in water (Jónasson 1945, 59-60). Waste residues from this treatment could account for the large concentrations of ectoparasites in the upper layer in room 5, while the lower numbers of these species present in the lower floor in rooms 2 and 5 suggest secondary processing (carding and spinning) ( $c f$. Buckland and Perry 1989).

The plant evidence indicates rubbish accumulation in this area, including the stones of two imported fruits, Prunus cf. spinosa (L.) and P. domestica (L.) and wood shavings from the non-indigenous trees Larix (larch) and Pinus (pine), probably representing driftwood. In sparsely wooded Iceland, driftwood, originating in Russia (Eggertsson 1993), constituted an important resource. Local birch, and seeds of plants likely to have been a food source, such as Empetrum nigrum (crowberry), and Arctostaphylos uva-ursi (bearberry), which was also used for making ink (Halldórsson 1989), were also found. Seaweed, commonly used as fuel and fodder as late as the early 20th century in Iceland, and as fertiliser (Kristjánsson 1980, 127), indicates contact with the coast. Fish bones were recovered from the floor layer in room 5 and in waste material found scattered in the upper layers at the farm. The main disposal of waste, however, will have been on the farm midden, which was destroyed during building activities in 1929 .

\section{Discussion}

The plant and insect evidence from inside the post medieval farm suggest that hay and peat were spread throughout the farm, probably to act as an absorbent litter layer. This is probably evidence for the maintenance of floors, material being spread to soak up residues and repair wet patches. Descriptions of the interiors of Icelandic farm dwellings by 19thcentury British travellers tend to stress their squalid conditions (Buckland et al. 1992, 162), although they may be coloured by the unfamiliarity of aristocratic British travellers with similar houses elsewhere. The insects found within the buildings indicate that the environment in the immediate vicinity of the farm was well drained, with sparse vegetation.

Grain was stored within the buildings, and this is likely to have been imported. Stronger evidence for trade is provided by the ants Hypoponera punctatissima (Roger) and Lepothorax sp., neither of which is indigenous to Iceland and probably accidentally brought into the site from continental Europe in packing material, and the presence of wood and fruitstones from plants which do not grow in Iceland, such as oak (Quercus), beech (Fagus), walnut (Juglans) and plum/sloe (Prunus). Local imports include driftwood and fish from coastal areas.

\section{The environmental investigations: (2) The medieval layers \\ Structure 10/11}

Two well preserved building foundations of medieval date were revealed underneath the passageway complex (Sveinbjarnardóttir 2001) (Fig. 4). Structure 10/ 11 featured at least two different building phases. This discussion centres on the earlier phase, which has been interpreted as the stone-built foundation or cellar for a wooden sunken building (Sveinbjarnardóttir 2006). The western end of the structure, where the underground passage from Snorralaug joined the building, was narrower than the rest of the building and the deposits found inside it suggested that it was a separate unit and served a different function. The structure appears to have had wooden panelling and post holes were present in each corner. It had several layers containing floor material, none of which covered the whole floor. Some animal bones, including the nearly complete skull of a sheep, were found in one of the upper layers in this building, context [456] (Fig. 5). It is suggested that a sheep carcase may have been left to rot inside the building, probably after it went out of use.

\section{Micromorphology}

Three undisturbed block samples were taken in $8 \times 6$ $\mathrm{x} 4 \mathrm{~cm}$ Kubiena tins from a section that exposed the lowermost layers in the western end of Structure 10/ 11 (micromorphology samples 52-4, Fig. 5). These block samples were dried by acetone replacement of water, impregnated with a crystic polyester resin, and thin sectioned following the procedures of Murphy (1986). Thin sections were described using the terminology outlined by Bullock et al. (1985) and Stoops (1993) (for thin section descriptions see Milek 2006).

Micromorphological analysis revealed that the three lowest contexts in the western end of Structure 10/11 represented two main depositional phases: a well-maintained sequence of clay floors (context [403] and the lower half of context [456]), on top of which was a sequence of rubbish deposits, presumably associated with the abandonment of the room (the upper half of context [456] and context [423]) (Fig. 5). The sequence of floor layers was lying directly on the natural subsoil, and had been 


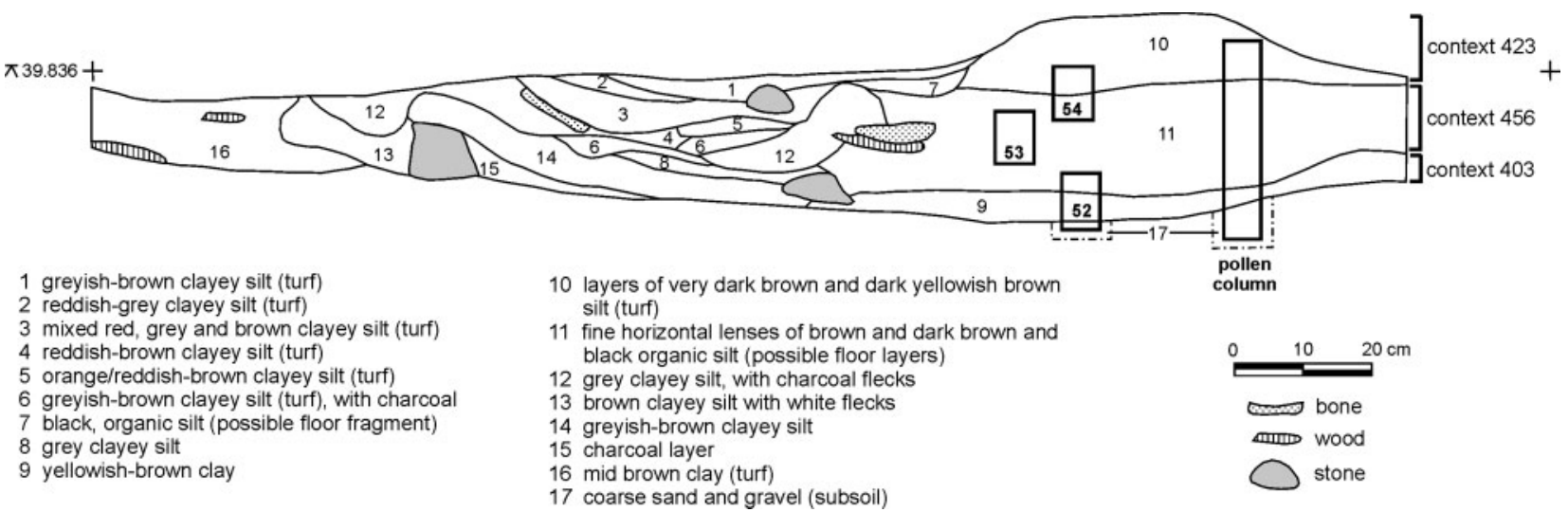

Figure 5 Section drawing showing locations of samples taken from structure 10. Facing south

interpreted during the excavation as a clay 'plaster' lining the inside of the structure.

Thin section analysis showed that the in situ floor layers consisted of multiple, alternating lenses of clean, yellowish-brown clay plasters and darker brown (stained) occupation surfaces (Fig. 6). The occupation surfaces contained horizontally oriented, microscopic inclusions, such as charred plant and/or wood fragments, bone fragments (Fig. $6 \mathrm{~g}$ ), and

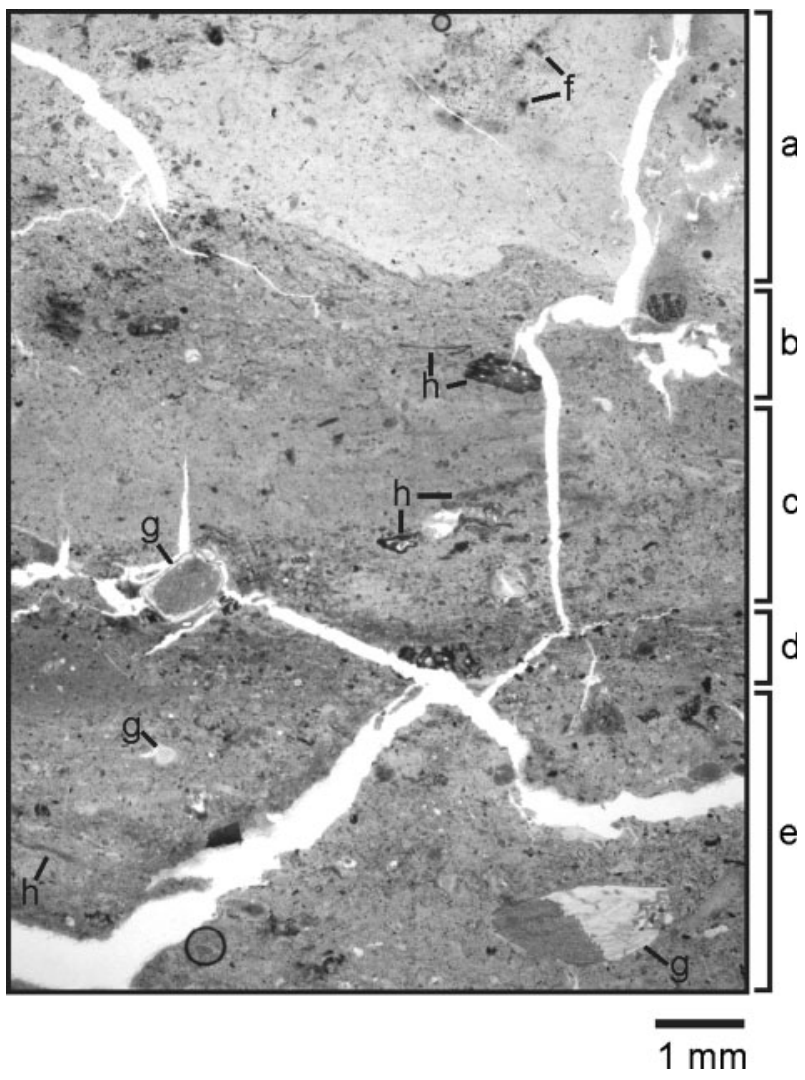

Figure 6 Micromorphology sample RKH00-52, from the lower half of context [456]. (a) clay floor; (b-e) multi-laminated occupation surfaces; (f) manganese dioxide nodules; (g) bone fragments; (h) partially decomposed plant tissues decomposed herbaceous plant matter (Fig. 6 h), all of which contributed to the darker colouring of these lenses. The horizontal orientation of these minute inclusions indicates that they accumulated on an accruing, horizontal surface. The occupation surfaces were also characterised by unistrial b-fabrics, in which the clay had a dominant horizontal orientation. This preferential orientation of the clay must have been caused by downward compression when the clay was damp, and is probably a product of trampling. Much of the charcoal in the occupation surfaces was silt-sized, and could be derived from airborne soot. The minute bone fragments that were present in many of the occupation deposits (including fish bone) suggest that food preparation or consumption took place nearby.

Altogether, the floors in this structure contained six applied clay layers, which ranged in thickness from 4 $26 \mathrm{~mm}$. On top of the uppermost clay layer, there was a thin layer of elongated strands of amorphous (fully decomposed) organic matter and phytoliths, which may be interpreted as strewn hay, and which was sealed by the last trampled occupation deposit. Throughout the sequence there were features resulting from alternating wet and dry conditions, including spherulitic siderite crystals, iron oxide nodules, and manganese dioxide nodules (Fig. 6 f).

The lenses in the upper half of context 456 were mixed, heterogeneous rubbish deposits, with a very different character from the occupation surfaces below. In thin section, they contained a mixture of bones, charred plant materials, aggregates of peat, and former floors made of clay and diatomaceous mud. Where it was captured in thin section, the uppermost context, 423, was also multi-layered, but it contained pieces of turf and a sequence of floor layers that had been dumped upside-down, which supports the field interpretation that this was dumped rubbish 
containing both turf and floor fragments, possibly a result of floor cleaning or repair elsewhere in the structure.

These results indicate that the small room in the western end of the cellar of Structure 10/11 had been well maintained and regularly used until it was abandoned and used to dispose of refuse.

\section{Context 577}

Parallel and to the north of structure 10/11, lay structure 12 (Fig. 4). It had a paved flag floor, covering an area $6.8 \times 3.5 \mathrm{~m}$ in size. A stone-built conduit ran into the building from the east, and is assumed to have carried steam from the hot spring to the east of the site (Sveinbjarnardóttir 2003, 26).

Partly overlying this conduit outside the entrance to the building, a deposit interpreted as a midden on account of its spread, outline and nature was encountered. It was very organic, with good preservation, and was fully excavated and extensively sampled. It was a maximum of $3.5 \times 4.0 \mathrm{~m}$ in extent and $c .27 \mathrm{~cm}$ thick, and consisted of a number of layers which were recorded as one context (577). The layering suggests accumulation over some time.

Seven vertical 5 litre samples $(68$, top, through to 73 and 75, base) were taken from context 577 in continuous slices, varying in thickness from 1 to $6.3 \mathrm{~cm}$, for the analysis of insect and plant macrofossil remains. A further five 3-5 litre samples (numbered 1, 2, 20-2) from across the top $5 \mathrm{~cm}$ of the midden were also subjected to insect analysis. Samples taken in five $5 \mathrm{~cm}$ thick spits $(64-7 ; 86)$, and a further basal sample (102) from a $1 \mathrm{~m}^{2}$ area within the midden were sub-sampled for pollen analysis. Animal bones and charred seeds in the deposit were

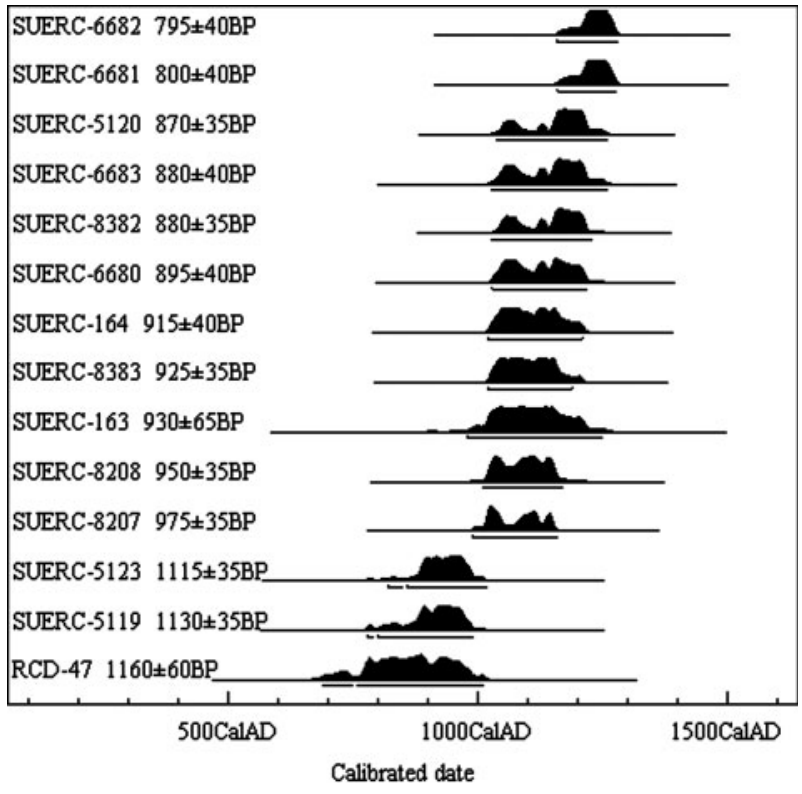

Figure 7 Multiplot of calibrated radiocarbon probability distributions for the age measurements from Reykholt. The lines below the probability distributions represent the two sigma levels (95.4\% confidence); calibration and diagram produced by OxCal v. 3.10 (Bronk Ramsey 2006)

AMS dated, with ${ }^{14} \mathrm{C}$ estimates falling between $c$. AD 1000 and 1200 (Table 1 and Fig. 7). It is clear that the dates for the deposit do not form a logical sequence. This can be accounted for by the way in which the material was deposited, subsequent slumping and bioturbation, including re-working and general human disturbance. Because of this and the fact that the calibrated ranges encompass a relatively short period in terms of a calibrated range (AD 980-1280), the results of the analyses will be discussed as a whole.

Table 1 Radiocarbon dates from Reykholt. All are AMS dates except for RCD-47. (Calibrations performed using OxCal v3.10; Bronk Ramsey 2006; Laboratory codes: RCD-RCD Radiocarbon Dating; SUERC-Scottish Universities Environmental Research Centre)

\begin{tabular}{|c|c|c|c|c|}
\hline Lab. No & Material & Sample no. and context & Age $\left({ }^{14} \mathrm{C}\right.$ yr BP; $\left.1 \sigma\right)$ & Calibrated Date (cal AD; $2 \sigma$ ) \\
\hline SUERC-5119 & Charred birch & RKH-87-S2, 15 & $1130 \pm 35$ & $\begin{array}{l}800-990 \\
780-990\end{array}$ \\
\hline SUERC-5123 & Charred birch & $\mathrm{RKH}-87-\mathrm{S} 1,15$ & $1115 \pm 35$ & $\begin{array}{l}820-1020 \\
860-1020\end{array}$ \\
\hline SUERC-8382 & Barley & 577 1a spit 1 & $880 \pm 35$ & $1030-1230$ \\
\hline SUERC-8383 & Barley & 577 1b spit 1 & $925 \pm 35$ & $1020-1190$ \\
\hline SUERC-6682 & Bone, Ovis & 577 spit 1 (RKH-01-SB61) & $795 \pm 40$ & $1160-1280$ \\
\hline SUERC-6680 & Bone, Ovis & 577 spit 2 (RKH-01-SB77) & $895 \pm 40$ & $1030-1220$ \\
\hline SUERC-6683 & Bone, Ovis & 577 spit 3 (RKH-01-SB80) & $880 \pm 40$ & $1030-1260$ \\
\hline SUERC-6681 & Bone, Ovis & 577 spit 4 (RKH-01-SB84) & $800 \pm 40$ & $1160-1280$ \\
\hline SUERC-163 & Seeds & 577 spit 5 (RKH-01-86) & $930 \pm 65$ & $980-1250$ \\
\hline SUERC-164 & Bone, Ovis & 577 spit 5 (RKH-01-100) & $915 \pm 40$ & $1020-1210$ \\
\hline $\mathrm{RCD}-47$ & Charred birch & RKH-89-S36 & $1160 \pm 60$ & $\begin{array}{l}690-1010 \\
760-1010\end{array}$ \\
\hline SUERC-5120 & Charred birch & RKHsmithy-01-S12 & $870 \pm 35$ & $1040-1260$ \\
\hline SUERC-8207 & Charred barley & RKH-89-S25 & $975 \pm 35$ & $990-1160$ \\
\hline SUERC-8208 & Charred barley & RKH-89-S25 & $950 \pm 35$ & $1010-1170$ \\
\hline
\end{tabular}




\section{Palaeoentomology}

All samples were sieved over $300 \mu$ mesh and subjected to paraffin (kerosene) floatation for the extraction of insect remains after the method developed by Coope and Osborne (1968). The floats were sorted under a low-powered light binocular microscope, and sclerites recovered were identified using relevant identification keys and a reference collection of modern Coleoptera, formerly housed in the Archaeology Department, University of Sheffield.

The beetle fauna from context [577] (Table 2) indicates that most of the material derived from within occupied buildings, and was similar to that from inside other medieval farms in Iceland ( $c f$. Buckland et al. 1993), with the consistent presence of obligate synanthropes (species dependant on the presence of people) some of which, such as Aglenus brunneus (Gyll.) and Tipnus unicolor (Pill.), have poor dispersal (and hence re-colonisation) ability. The faunas from each sample were remarkably consistent, suggesting that the deposit had been formed by repeated deposition from similar source buildings. The assemblage shows that the immediate environment around the site included dry ground with sparse vegetation, typical for example of the carabid Amara quenseli (Schön.) (Larsson and Gígja 1959, 42). The wider environment was represented by species associated with heathland, meadow and bog. A comparison with insect assemblages from peat samples from the floodplain adjacent to Reykholt (Vickers 2006) shows that the majority of the meadow and heath species recovered from context [577] are not present in natural pre-Landnám deposits nearby. This suggests that the specimens do not derive from local peat and they are probably contemporary with the deposit. There was, however, evidence in the form of water beetles and Trichoptera (caddis fly) larvae of peat having been used in the source buildings, probably either as litter or fuel. The presence of moss is suggested by Gymnusa brevicollis (Payk.) and Lathrobium brunnipes (F.), and this is also apparent in the plant macrofossil remains (Guðmundsson 2002), although this is not evident in the pollen analyses (see below). Both species of beetle and the mosses are typical of wetlands, and their remains probably represent fossils in peat rather than contemporary material.

Synanthropic species dominate the assemblage. The majority are typical of dry mouldy indoor conditions, often associated with stored hay in the North Atlantic region. These include Lathridius minutus (grp.), species of Cryptophagus, Corticaria elongata (Gyll.), and predatory rove beetles, Xylodromus concinnus (Marsh.), X. depressus (Grav.) and Quedius mesomelinus (Marsh.) (Lindroth et al. 1973). Although some species typically forming part of this assemblage in the North Atlantic were absent, the pollen data discussed below suggest that waste hay did form part of the deposit, in which many of these beetles were probably living, while some of the species associated with meadow habitats may have been introduced to the deposit in hay.

Aglenus brunneus (Gyll.) has only one recent Icelandic record (Larsson and Gígja 1959, 147), but it was present in most of the Reykholt samples. It is characteristic of old sour grain residues and other warm anthropogenic accumulations, such as rotting vegetation and manure. It was probably introduced to the site in imported grain, and its survival may be connected to the warmth provided by the hot springs at the site. It is a common insect in a range of medieval urban deposits in Britain (Kenward 1975; 1976).

Small numbers of sheep ectoparasites suggested that wool processing may have taken place in the buildings from which the deposit derives. Although some species associated with dung and foul rotting materials were present, significant quantities of animal waste are unlikely to have formed part of the midden. Species living on foul residues are commonly found in archaeological floor layers in the North Atlantic region (Perry et al. 1985; Amorosi et al. 1992; Buckland et al. 1994), and their limited presence in the Reykholt samples suggests that the buildings from which the deposit derives shared similar conditions

\section{Plant macrofossil and pollen analysis}

Plant macrofossils were recovered by disaggregation over a $300 \mu \mathrm{m}$ sieve and sorting under a low power binocular microscope. They included barley and other plants used for human consumption, such as crowberries and chickweed (Stellaria sp.), although the latter is likely to have grown in profusion around the site, were recovered from the deposit, as well as large quantities of club- and/or spike moss (Lycopodium/Selaginella) (Guðmundsson 2002).

Pollen samples of $1 \mathrm{~cm}^{3}$ volume were pre-treated with standard $\mathrm{NaOH}, \mathrm{HF}$ and acetolysis methods (Faegri and Iversen 1989) and Lycopodium spores were added for the calculation of palynomorph concentrations (Stockmarr 1971). The samples were mounted in silicone oil. Pollen counts of $c .500$ grains of total land pollen were made at each level. Pollen 
Table 2 Species list of the insects recovered from context 577. (MNI, Taxonomy follows Lucht, 1987). a = samples analysed by Vickers. ${ }^{b}=$ samples analysed by Buckland (2005) Key to habitat codes: p: parasite, aq: aquatic, d: dung, eu: eurytopic, he: dry ground/ heath, m: moss/litter, rd: rotting dry waste, rf: rotting foul waste, ri: riparian, rt: rotting general waste, rv: rich vegetation, sv: sparse vegetation. Note: codes are generalised and do not cover the full range of habitats many of these species may be found in

\begin{tabular}{|c|c|c|c|c|c|c|c|c|c|c|c|c|c|}
\hline Sample & & $\pi$ & స̆ & "̊̊ి & $\stackrel{\pi}{\bar{N}}$ & స̃ & $\stackrel{\circ}{\infty}$ & ค̊. & $\stackrel{\circ}{R}$ & $\stackrel{0}{r}$ & $\stackrel{\circ}{N}$ & $\stackrel{n}{p}$ & 负 \\
\hline Sample depth (in cm) & & in & in & $\dddot{1}$ & in & ns & $\begin{array}{l}3 \\
6 \\
0\end{array}$ & 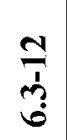 & $\frac{\ddot{a}}{\grave{d}}$ & 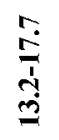 & $\begin{array}{l}\bar{T} \\
\stackrel{5}{\Xi} \\
\end{array}$ & $\frac{\bar{S}}{\bar{T}}$ & $\frac{\bar{c}}{\frac{1}{4}}$ \\
\hline Volume processed (in Litres) & & 5 & 5 & 5 & 3 & 3 & 2 & 2 & 2 & 2 & 2 & 2 & 2 \\
\hline Species & $\begin{array}{c}\text { Habitat } \\
\text { code }\end{array}$ & & & & & & & & & & & & \\
\hline \multicolumn{14}{|l|}{ Anoplura: } \\
\hline Pediculus humanus (L.) & $p$ & & & & & & & 1 & 2 & & & & \\
\hline Damalinia ovis (L.) & $p$ & & & & & & & & & & & 1 & \\
\hline \multicolumn{14}{|l|}{ Trichoptera: } \\
\hline Trichoptera indet. (larvae) & aq & & & & & & 1 & & & & 1 & & \\
\hline \multicolumn{14}{|l|}{ Coleoptera: } \\
\hline Nebria rufescens (Strom.) & eu & & & & 2 & & & & & 1 & & & \\
\hline Bembidion bipunctatum (L.) & sv & 3 & 1 & 3 & 2 & 1 & & & 1 & 1 & & 3 & 1 \\
\hline Bembidion grapii (Gyll.) & sv & 1 & & & & 1 & & 1 & & & & & \\
\hline Patrobus septentrionis (Dej.) & $\mathrm{rv}$ & & 1 & & & & & & & 1 & 1 & & \\
\hline Patrobus sp. & & & & 1 & & & & & & & & & \\
\hline Trichocellus cognatus (Gyll.) & he & & & & & & & & 1 & & & & \\
\hline Pterostichus adstrictus (Esch.) & he & & & & 1 & & & & & & & & \\
\hline Pterostichus diligens (Strm.) & $\mathrm{rv}$ & & 1 & 1 & & & & & & 1 & & 1 & \\
\hline Calathus melanocephalus (L.) & he & 2 & 2 & 1 & 2 & 1 & & 1 & 1 & 2 & & & 2 \\
\hline Laemostenus terricola (Hbst.) & rf & & & & & & & & & 1 & & & \\
\hline Amara quenseli (Schoen.) & sv & 1 & & & 2 & 1 & & & & & & & \\
\hline Amara sp. (not quenseli) & & & & & 1 & & & & & & & & \\
\hline Hydroporus nigrita (F.) & aq & 3 & 4 & 1 & 1 & 1 & & 2 & 2 & 1 & 8 & 5 & 1 \\
\hline Agabus bipustulatus (L.) & $\mathrm{aq}$ & & & & & & & & 1 & 1 & 1 & 1 & \\
\hline Agabus sp. & $\mathrm{aq}$ & & 1 & & & 1 & & & & & & & \\
\hline Steinichnus collaris (Müll.) & he & & & & & & & & & & 1 & & \\
\hline Phyllodrepa floralis (Payk.) & it & & 6 & 3 & & 1 & & 1 & 1 & & 2 & 2 & 1 \\
\hline Omalium rivulare (Payk.) & $\mathrm{rt}$ & & & 1 & & & & & & & 1 & 1 & \\
\hline Omalium septentrionis (Thom.) & it & & & 1 & & & & & & & & & \\
\hline Omalium excavatum (Steph.) & $\mathrm{rt}$ & 3 & & 2 & 4 & 2 & & 5 & 2 & & 1 & 2 & 8 \\
\hline Omalium sp. & rt & & & & & & & & 2 & & & & 1 \\
\hline Xylodromus depressus (Grav.) & rd & 1 & & & 1 & & & & & & & & \\
\hline Xylodromus concinnus (Marsh.) & $\mathrm{rd}$ & 9 & 2 & 3 & 3 & 5 & & 3 & 5 & 2 & 3 & 2 & \\
\hline Lesteva longoelytrata (Goez.) & $\mathrm{rv}$ & 1 & & & 1 & & & & & 3 & & & \\
\hline Stenus umbratilis (Casey) & ri & & & & & 1 & & & & & 1 & & \\
\hline Stenus spp. & & 5 & 3 & 4 & 4 & 2 & & 2 & 3 & 3 & 2 & 2 & \\
\hline Lathrobium brunnipes (F.) & $\mathrm{m}$ & 1 & 2 & 1 & 2 & & & & & 1 & & & \\
\hline Lathrobium sp. & & & & & & & & & & & 1 & & \\
\hline Othius angustus (Steph.) & $\mathrm{m}$ & & & & & & & & 7 & 1 & 1 & & \\
\hline Philonthus politus (L.) & rf & & & 1 & & & & & & & & & \\
\hline Philonthus cephalotes (Grav.) & if & 1 & 2 & 1 & & & & 1 & & & & 4 & \\
\hline
\end{tabular}


Table 2 (Continued)

\begin{tabular}{|c|c|c|c|c|c|c|c|c|c|c|c|c|c|}
\hline Sample & & 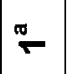 & กั & ్ & $\bar{\sim}$ & స̃ & $\stackrel{\circ}{\infty}$ & $\stackrel{8}{8}$ & $\stackrel{\circ}{\circ}$ & $\stackrel{0}{i}$ & $\stackrel{\cap}{N}$ & $\stackrel{n}{R}$ & م \\
\hline Sample depth (in $\mathrm{cm}$ ) & & $\begin{array}{c}n \\
0\end{array}$ & $\begin{array}{l}n \\
0 \\
0\end{array}$ & 8 & $\begin{array}{l}n \\
0 \\
0\end{array}$ & $\stackrel{1}{\delta}$ & $\begin{array}{l}3 \\
0 \\
0\end{array}$ & $\mid \begin{array}{c}\mathcal{y} \\
\bar{n} \\
\text { nु. }\end{array}$ & 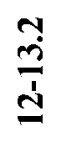 & $\begin{array}{l}\stackrel{2}{\hat{j}} \\
\dot{1} \\
\stackrel{2}{2}\end{array}$ & $\begin{array}{l}\bar{T} \\
\stackrel{1}{I} \\
I\end{array}$ & $\frac{\bar{\oplus}}{\frac{1}{N}}$ & $\frac{1}{1}$ \\
\hline Volume processed (in Litres) & & 5 & 5 & 5 & 3 & 3 & 2 & 2 & 2 & 2 & 2 & 2 & 2 \\
\hline Species & $\begin{array}{c}\text { Habitat } \\
\text { code }\end{array}$ & & & & & & & & & & & & \\
\hline Gabrius sp. & rv & 6 & 3 & 7 & 4 & 1 & & & & & & 1 & \\
\hline Creophilus maxillosus (L.) & $\mathrm{rf}$ & & & & & & & & & 1 & & 1 & \\
\hline Quedius mesomelinus (Marsh.) & $\mathrm{rt}$ & 1 & 2 & 1 & 4 & 1 & & & & & 1 & 2 & \\
\hline Quedius umbrinus (Er.) & $\mathrm{m}$ & 1 & 3 & 2 & 2 & 1 & & & 1 & 4 & 2 & 4 & \\
\hline Quedius boops (Grav.) grp & eu & & & 1 & & & & & & 1 & & 1 & \\
\hline Gymnusa brevicollis (Payk.) & $\mathrm{m}$ & 1 & & & & & & & & 1 & & & \\
\hline Oxypoda sp. & & & & & & & & & & & & & 1 \\
\hline Aleochara sparsa (Heer.) & $\mathrm{rf}$ & & & & & & & & 1 & & 1 & 1 & \\
\hline Aleochara sp. & & 5 & 4 & & & & & & & & & & \\
\hline Atheta sp. & & & & & & 7 & & & & & & & \\
\hline Aleocharinae gen. indet. & & 28 & 10 & 18 & 17 & 3 & 2 & 5 & 12 & 8 & 6 & 4 & 3 \\
\hline Bryaxis puncticollis (Denny) & $\mathrm{m}$ & 1 & & & & & & & & & & & \\
\hline Hypnoidus riparius (F.) & $r v$ & 1 & 2 & 1 & 1 & 1 & 1 & & & & & 1 & \\
\hline Byrrhus fasciatus (Forst.) & $\mathrm{sv} / \mathrm{m}$ & & 1 & & 1 & 1 & & & 1 & & 1 & 1 & \\
\hline Cryptophagus scutellatus (Newm) & $\mathrm{rd}$ & & & & & & & & & & & 1 & \\
\hline Cryptophagus spp. & $\mathrm{rd}$ & 6 & 1 & 2 & 1 & 3 & & 3 & 4 & 2 & 2 & & \\
\hline Atomaria cf. apicalis (Er.) & $\mathrm{rt}$ & & & & 1 & & & & & & & & \\
\hline Atomaria spp. & $\mathrm{rt}$ & 2 & 2 & & 2 & 5 & & & 2 & 2 & 2 & 2 & 4 \\
\hline Lathridius minutus (grp.) & $\mathrm{rd}$ & 32 & 13 & 4 & 32 & 11 & 2 & 21 & 18 & 10 & 4 & 5 & 5 \\
\hline Corticaria elongata (Gyll.) & $\mathrm{rd}$ & 19 & 2 & 4 & 14 & 8 & & 9 & 15 & 4 & 1 & 1 & 1 \\
\hline Aglenus brunneus (Gyll.) & $\mathrm{rt}$ & 9 & 4 & 1 & 13 & 5 & & 3 & 3 & 2 & 1 & 2 & \\
\hline Tipnus unicolor (Pill. \& Mitt.) & $\mathrm{rt}$ & 1 & & & & & & 1 & & & 1 & & \\
\hline Aphodius lapponum (Gyll.) & $d$ & & 1 & 1 & 1 & 1 & & 1 & & 1 & 1 & 1 & \\
\hline Otiorhynchus arcticus (F.) & he & 5 & 4 & 2 & 2 & 9 & & 3 & 1 & 1 & & 1 & \\
\hline Otiorhynchus nodosus (Müll.) & he & 1 & & & 1 & & & & 2 & 1 & & 1 & 1 \\
\hline Otiorhynchus sp. & & & & 1 & & & & & & & & & \\
\hline Hypera suspiciosa (Hbst.) & $\mathrm{rv}$ & & & & & 1 & & & & & & & \\
\hline Tropiphorus obtusus (Bons.) & $\mathrm{rv}$ & 1 & 1 & 1 & 1 & 2 & & 1 & & & 1 & 1 & 1 \\
\hline \multicolumn{14}{|l|}{ Diptera: } \\
\hline Melophagus ovinus (L.) & $p$ & & & & 1 & & & & & & 1 & 1 & 3 \\
\hline Total & & $\underline{6}$ & $\stackrel{\infty}{\uparrow}$ & $R$ & $\underset{\sim}{\sim}$ & $N$ & $\boldsymbol{0}$ & $\Xi$ & $\stackrel{\infty}{\infty}$ & iొ & \& & i̊ & $\tilde{m}$ \\
\hline
\end{tabular}


and spore identification was undertaken using mainly the key of Moore et al. (1991). Betula (birch) pollen was differentiated into its tree and dwarf components by size class measurements (e.g. Caseldine 2001), and the diameter of Poaceae (grass) pollen grains and their annuli were also measured in an attempt to differentiate any cereal components in the pollen rain (Andersen 1979; Tweddle et al. 2005). Microscopic charcoal was recorded using the point-count method (Clark 1982). Organic content of pollen samples was determined by loss-on-ignition (LOI), involving 3 hours combustion at $550^{\circ} \mathrm{C}$ (e.g. Heiri et al. 2001).

The pollen analysis showed little evidence of stratification within the deposit, although it could be divided into two assemblages (Fig. 8). The lower assemblage (zone 1) reflected the floral composition reminiscent of a midden and the weed taxa (Cerastium-type, Polygonum aviculare L., Montia fontana L., Rumex spp.) are likely to have grown on dry and sparsely vegetated ground on and around a midden. High concentrations of microscopic charcoal serve to suggest that domestic litter had at some stage been dumped with this material. The high concentrations of Poaceae do not suggest that these contexts consist to a large extent of peaty materials, although some taxa indicate damp conditions, e.g. Caltha palustris L., Filipendula ulmaria L. and Apiaceae spp. The majority of the pollen in zone 1 was typical of dry meadow and pasture communities (Steindórsson 1964; 1981), and the assemblage compares well with pollen data from post-landnám contexts from a nearby palaeochannel on the Reykjadalsá floodplain (Erlendsson 2007).

The upper assemblage (zone 2) shows more limited signs of domestic litter accumulation. The pollen assemblages almost directly correspond to those found in grazed, post-landnám vegetation communities ( $c f$. Hallsdóttir 1982; 1987) in Reykholtsdalur (Erlendsson 2007), and it is likely that context [577] represents the clearing-out of hay litter either from barns or from human quarters, where these pollen assemblages might have been formed from the collecting of winter fodder from meadows. Some evidence can be found for the incorporation of peat in the midden deposits. Typical wetland taxa (e.g. Apiaceae spp. Filipendula ulmaria, Caltha palustris and Cyperaceae) are present, although in relatively low numbers, but might represent fossil components in the pollen assemblages as suggested for the wetland beetle taxa. It should be remembered, however, that wetlands were an important source for fodder. Hence, the presence of both pollen and insects in the midden deposits indicative of wetland environments might, to any extent, also be the result of the mowing and gathering of wetland vegetation.

Cereal pollen, found in all samples from context [577], suggests that oats and barley were cultivated by the farmers at Reykholt. This is further supported by pollen-analytical data from contexts near Reykholt which suggest that the cultivation of barley took place during the middle ages, although analyses have so far failed to detect oat cultivation (Erlendsson 2007). This does not disprove the cultivation of oats in Reykholt, as this might simply have been undertaken further from the sampling site ( $c f$. Erlendsson et al. 2006). Whilst the insect fauna lacks obligate grain pests, the presence of Aglenus brunneus implies importation of cereals at some stage, although it may have arrived with the primary seed corn.

\section{Micromorphology}

Five overlapping samples of midden material were collected in $8 \times 5 \times 5 \mathrm{~cm}$ Kubiena tins for the preparation of thin sections (76, upper, through to 80 , lower), covering the full thickness of the $c .27 \mathrm{~cm}$ deposit together with an underlying soil. Preliminary examination identified the undisturbed and intact underlying soils as a peaty podsol with a sharp boundary to heterogeneous and complex midden material. It was separated towards the upper part by a phase of in situ peaty loam (silt) formation. This is likely to represent a change in deposition location on the midden rather than cessation of waste deposition.

The deposit consisted of a range of intermixed fuel residues, animal manures, and wastes derived from site construction activity (Table 3 ). This includes occupation surface wastes characterised as diatomaceous material intermixed with striated clays, similar to the clay and diatomaceous mud floor surfaces that had been dumped in structure 10/11 (see above) and had originally been dug from wetland areas. The turf contained varying frequencies of iron features, suggesting that turf from both drier and wetter sources had been introduced to the site, probably as material for walling.

Dominant features in thin section were fuel residues suggesting a mixed fuel economy, with wood (Fig. 9), probably birch, and peat both being exploited. The fuel residues exhibited characteristics of high temperature (greater than $800^{\circ} \mathrm{C}$ ) and low temperature (up to $400^{\circ} \mathrm{C}$ ) burning, indicating that fuels could have been used for metal working as well as for domestic purposes - cooking, light and heat. Above the in situ peaty loam formation that separated the midden horizons, residues of 


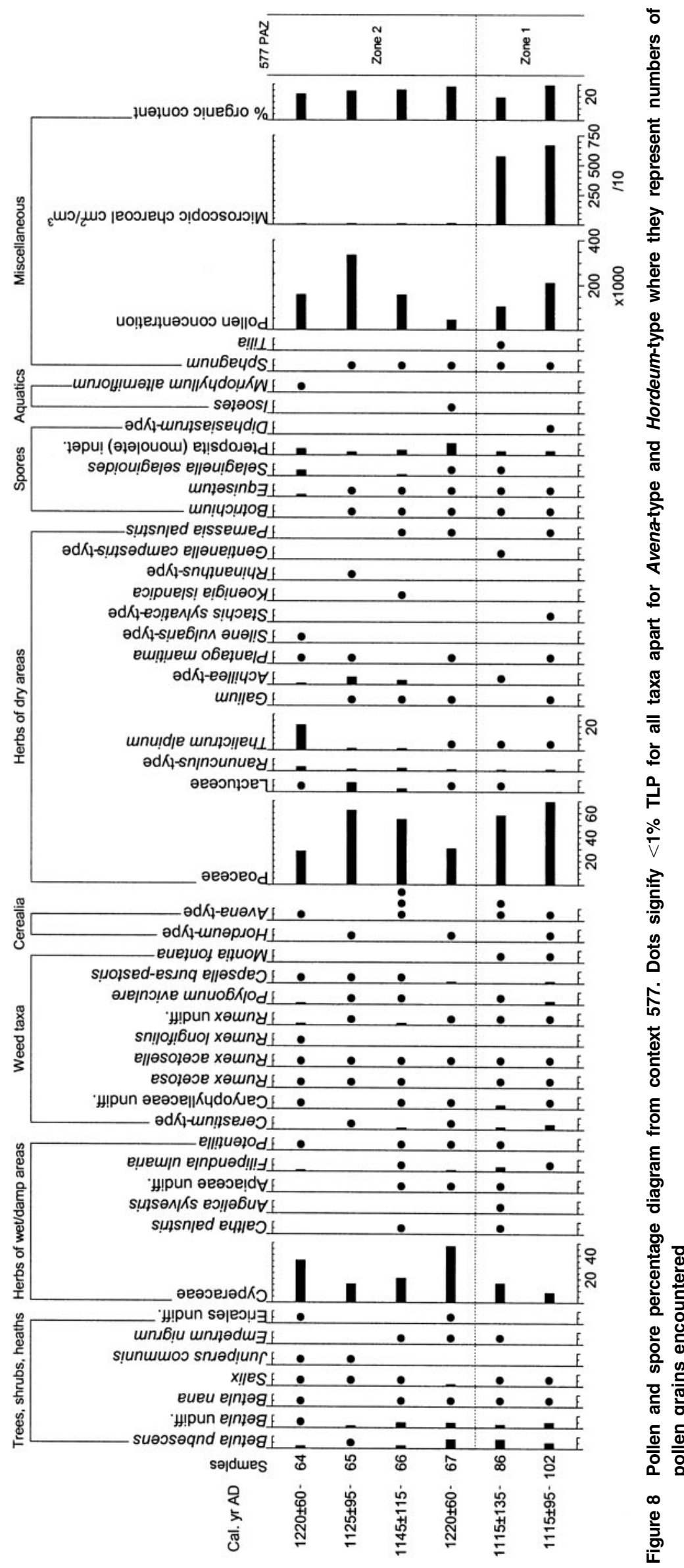




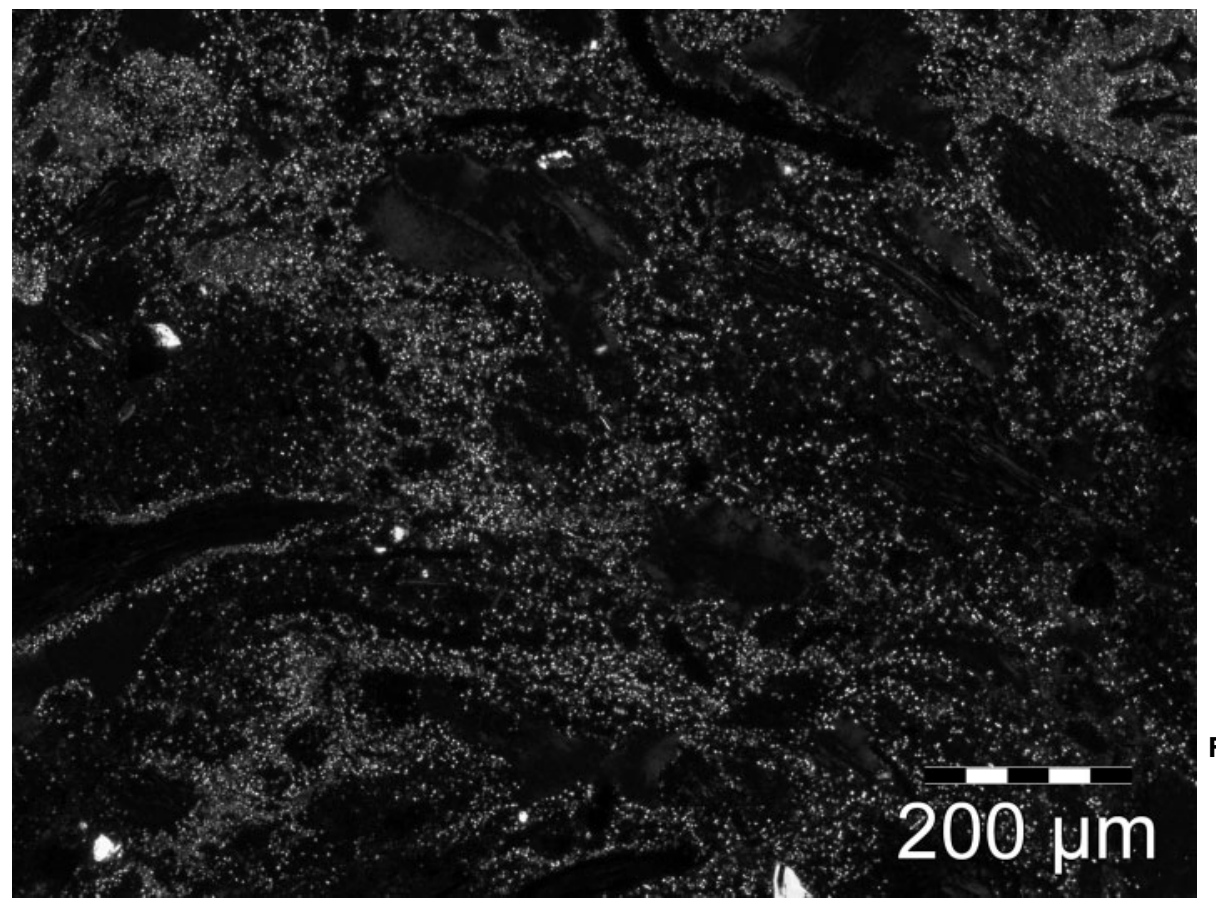

Figure 9 Crystallitic b (birefringent) fabrics derived from wood ash. Context 577, sample 77

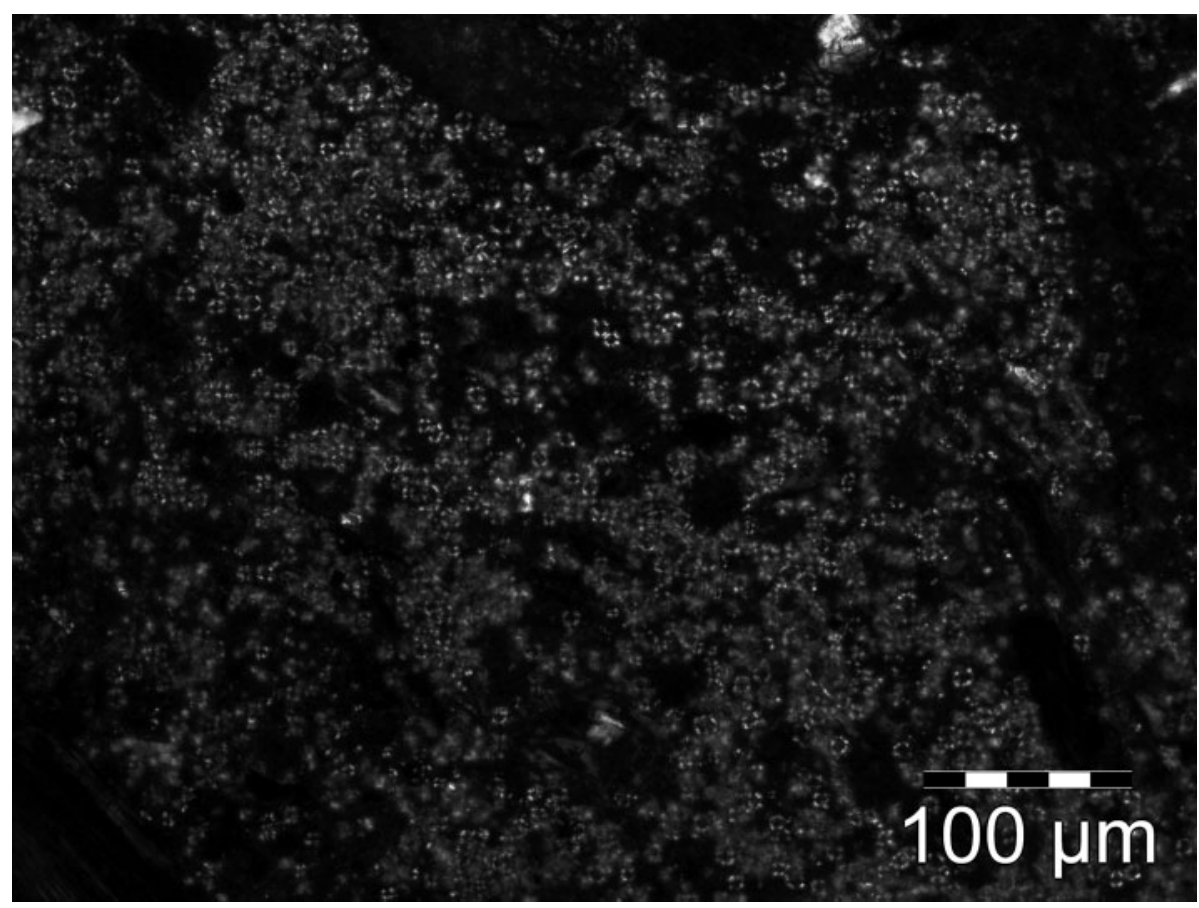

Figure 10 Spherulites derived from faecal material. Context 577, sample 77. Cross polars

combusted peat were still prevalent, but the crystallitic birefringence fabrics indicative of wood ash disappeared and grey fibrous material indicative of combusted animal dung became evident. This suggests an emerging shortage of wood for fuel, demonstrated also by the pollen evidence from Reykholtsdalur (see above), which is likely to have been offset by the use of animal dung, evidence of which was found in the fireplace [99], discussed below.
Unburnt animal dung, evidenced by occurrences of calcium carbonate faecal spherulites (Fig. 10) associated with fragmented and partially decomposed organic material, was also found in some parts of the midden stratigraphy, indicating that not all manure was used for fuel or taken out to the fields as fertiliser. The presence of animal manure is not, however, supported by the low numbers of beetle species associated with foul residues recovered from the midden. Although the build up of toxins in 
Table 3 Description and interpretation (based on experimental observation) of key micromorphological features observed in context [577], Reykholt

\begin{tabular}{|c|c|c|}
\hline Feature attributes & Feature interpretation & Thin section Location \\
\hline $\begin{array}{l}\text { Crystallitic b-fabrics, intermixed with fine black } \\
\text { amorphous material; commonly iron stained. } \\
\text { Wood charcoal adjacent }\end{array}$ & $\begin{array}{l}\text { Fuel residue - wood ash, probably birch } \\
\text { (Simpson et al. 2003) }\end{array}$ & Sample: 77787980 \\
\hline $\begin{array}{l}\text { Rubified material with diatoms and fine black } \\
\text { amorphous material }\end{array}$ & $\begin{array}{l}\text { Fuel residue - peat ash, low temperature } \\
\text { burning (Simpson et al., 2003) }\end{array}$ & Sample: 7677787980 \\
\hline $\begin{array}{l}\text { Pale yellowed material with diatoms and } \\
\text { non-metallurgical slag }\end{array}$ & $\begin{array}{l}\text { Fuel residue - peat ash, high temperature } \\
\text { burning (Simpson et al., 2003) }\end{array}$ & Sample: 7677787980 \\
\hline $\begin{array}{l}\text { Grey, fibrous material. Fractured and fused } \\
\text { siliceous phytoliths. }\end{array}$ & Combusted animal manure (Simpson et al., 2003) & Sample: 76 \\
\hline $\begin{array}{l}\text { Spherulites intermixed with fragmented } \\
\text { parenchymatic tissue; fractured phytoliths }\end{array}$ & Domestic livestock manures (Canti, 1997) & Sample: 77 \\
\hline $\begin{array}{l}\text { Dark organo-mineral material with parenchymatic } \\
\text { tissue, fungal spores and hyphae }\end{array}$ & $\begin{array}{l}\text { Uncarbonised turf material (Adderley et al., } \\
\text { 2006), possibly walling }\end{array}$ & Sample: 7677787980 \\
\hline Diatomaceous material, intermixed with striated clays & Flooring material cleared out of structures & 76777879 \\
\hline Angular silt accumulations & Wind-blown deposits & Sample: 77 \\
\hline
\end{tabular}

manure within an enclosed byre has been shown to prohibit the colonisation of this habitat by a beetle fauna, when old byre material is removed to a midden, a fauna associated with foul waste might be expected to develop (Smith 1998).

\section{Zooarchaeology in the medieval layers}

The conditions of bone preservation at Reykholt were extremely variable, with the larger midden deposits (to a large extent truncated by the school building) unfortunately showing acid soils in the $\mathrm{pH}$ range of 5.25-6.0 and only sporadic bone preservation. The deposits from within and directly around the medieval and early modern structures sometimes provided better conditions of preservation, but overall the taphonomic conditions at Reykholt must be seen as marginal for bone preservation. While these taphonomic issues restrict a fully quantitative presentation of the bone material, the surviving archaeofauna provides some useful patterning. Table 4 presents the identified bones (total NISP $=150$ ) and the total fragment count (total TNF $=667$ ) by context.

As Table 4 indicates, the majority of bone came from contexts [577] (early medieval) reported in this section, and also from [704] (later medieval). Domestic mammals included cattle, horse, sheep, a single goat bone from context [577], and pig (contexts [646], just above [577], and [647] in the wall of structure 12). Pigs were introduced by the earliest settlers, but are thought to have diminished

Table 4 Animal bones excavated in 2000-2002. 'Caprines' are sheep and goat combined for comparative purposes, LTM are large terrestrial mammals (horse or cattle sized), MTM are medium terrestrial mammals (sheep or pig sized), and UNI are unidentified fragments

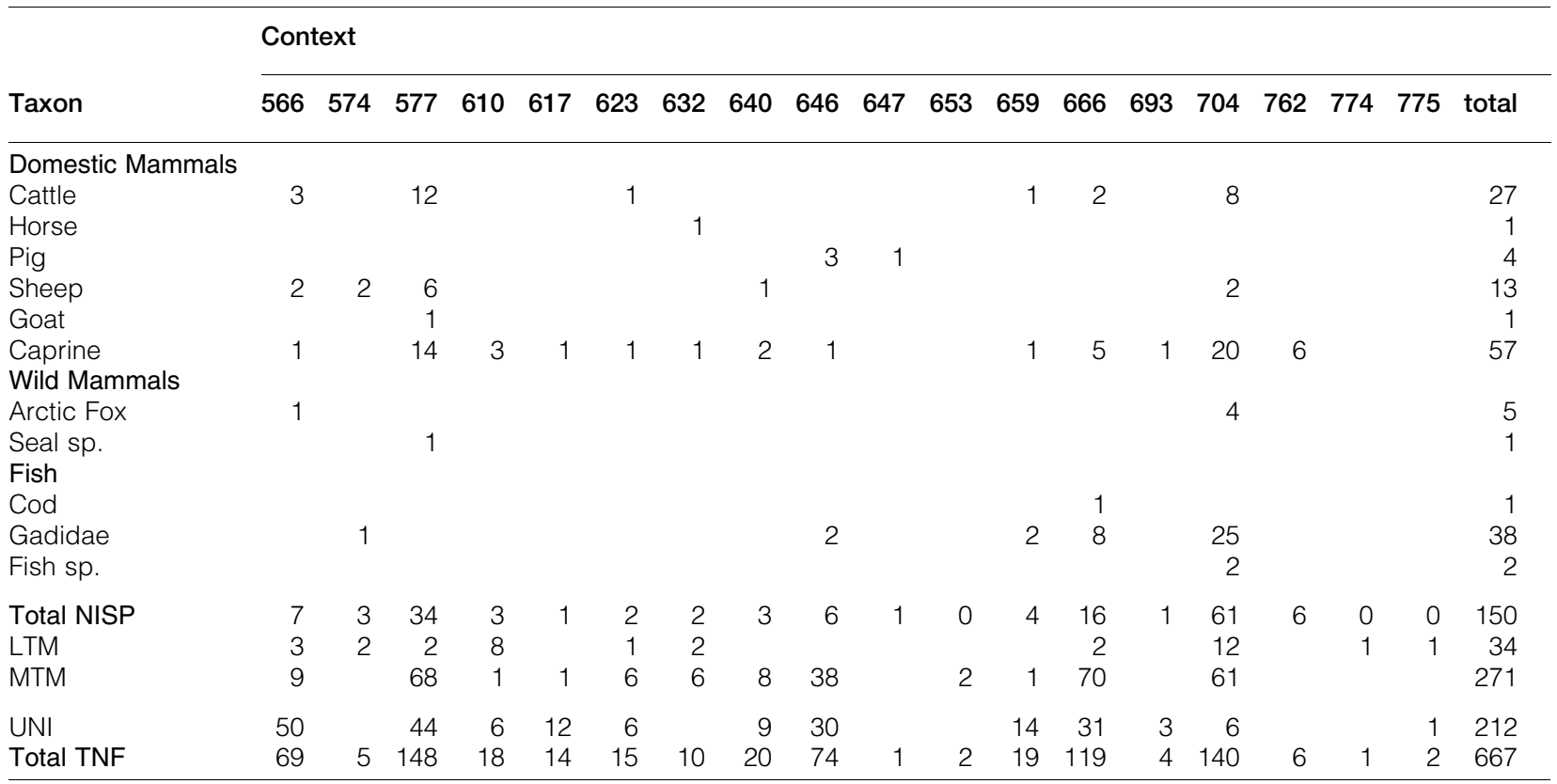


drastically by the 17 th century, not least because of the lack of woodland on which they fed (Einarsson 1971, 101-2). Young (neonatal) calf bones were recovered from contexts [566] (peat ash in last phases) ( 1 of 3 cattle bones), [577] ( 2 of 12 cattle bones), [666] (peat ash in last phases) (1 of 2 cattle bones), and [704] (1 of 8 cattle bones). The normal dairy management strategy of ordinary Icelandic farms from settlement to recent times has generated relative percentages of cattle neonatal bones ranging from $30-50 \%$ of identified cattle.

One seal bone was found in context [577]. A seal bone was also found at Háls in Hálsasveit, a small farm further up the valley, occupied between $c$. AD 1000 and 1275 (Smith 2005). This shows exploitation of maritime resources at these inland sites in the medieval period. A fragment of a sea shell was also found in the deposit (Guðmundsson 2002).

The fish bones present at Reykholt were all marine, falling into the cod family (Gadidae) with one thoracic vertebra (from context [666]) identifiable as Atlantic cod (Gadus morhua L.). While the small sample size and conditions of preservation limit interpretation, the current skeletal element distribution pattern (Table 5) suggests that these marine fish were transported inland as some type of preserved fish product. Table 5 presents both the raw bone fragment count (NISP) and the MAU \% (MAU normalises for the different natural frequency of bones in the skeleton). Skull and jaw parts were completely missing, and thoracic vertebrae were relatively abundant, suggesting the transport inland of a product similar to the later stockfish, which (unlike flat dried products) contained most of the vertebral column (for discussion see Krivogorskaya et al. 2005).

The presence of marine products on this inland site appears to be an example of what seems to have been an extensive exchange of fish (and probably other marine products) within Iceland from the early Middle Ages (Edvardsson and McGovern 2005; Amundsen et al. 2005).

Table 5 Fish bones from Reykholt

\begin{tabular}{lcc}
\hline Reykholt: all Gadidae & NISP & MAU \% \\
\hline Skull and Jaws & 0 & 0 \\
Cleithrum \& Thoracic Girdle & 0 & 0 \\
Thoracic vertebrae & 13 & 76.61 \\
Precaudal vertebrae & 8 & 9.92 \\
Caudal vertebrae & 16 & 13.47 \\
\hline
\end{tabular}

\section{The earliest occupation phase}

Below the kitchen area of the post-medieval farm complex and pre-dating structure 10/11, an elongated hollow dug into the natural substrate, with the remains of a stone setting and a box at one end, was interpreted as a long hearth [99]. $\mathrm{A}{ }^{14} \mathrm{C}$ date on charred barley from the box gave an estimate falling between the 10th and 12th centuries AD (SUERC8207 and 8208), whereas a sample of charred birch from the natural substrate below the fireplace produced an estimate that fell between the 8th and early 11 th centuries AD (RCD-47). The charcoal may indicate woodland clearance, evidence of which has been found at other sites in Iceland (Pórarinsson 1974), or other human activity at the site before it was occupied ( $c f$. Smith 2005). Unfortunately, the immediate area around the fireplace was badly truncated by later building activities. Remains of a turf wall containing the landnám tephra, dated to AD $871 \pm 2$ (Grönvold et al. 1995), with associated remains of floor layers (15), dated on the basis of charred birch to the 9th century (SUERC-5123 and 5119), were found close to the fireplace, but could not be associated with it.

Radiocarbon dating on charred birch, the main indigenous tree found in Iceland, has in many instances produced dates which are considerably earlier than other strands of evidence (Sveinbjörnsdóttir et al. 2004). There may be several reasons for this, namely that the wood was driftwood, derived from peat, or dead wood which was old when burnt. It has also been suggested that carbon derived from either marine or volcanic sources may have affected results (Olsson and Vilmundardóttir 2000). Animal bone and charred barley seeds, both of which have a more secure short lifespan, are therefore more reliable for radiocarbon dating in Iceland and are used to date the site, although any marine input to animal food will clearly be reflected in the dates.

The sample containing the charred barley also included many weeds associated with barley growing. The small size of the barley grains (indicating harsh growing conditions), and the associated weeds prompted the suggestion that it may have been grown locally (Hillman 1991).

Cereal growing at Reykholt is mentioned in the earliest preserved church charter dated to 1185 or earlier (DI I, 279-80), and again in 1224 (DI I, 466), but not in 1358 (DI I, 122-3), by which time it may have ceased. Iceland is on the margins of viable cereal cultivation, and only barley and oats could be 
cultivated. There is written and place name evidence to suggest that cereal was grown in climatically favourable places from the time of settlement until the 15 th century when the practice was abandoned, perhaps because at that time reasonably priced imported grain became available (Einarsson 1963, 457). The cessation of barley cultivation at Reykholt does not appear to be caused by temperature deterioration. Chironomid-inferred temperature reconstructions from Breiðavatn, about $5 \mathrm{~km}$ to the north-east, indicate that mean July temperatures remained fairly stable until $c$. AD 1400 , when the Little Ice Age brought them down by about $1{ }^{\circ} \mathrm{C}$ (Gathorne-Hardy pers comm).

An unusual feature of the sample from fireplace [99] was the complete absence of wood charcoal, whereas remains of peat or dung were found (Hillman 1991). Wood and peat were used as fuel in Iceland (see e.g. Jarðabók 4, 231, 241-4), as was dung, particularly in the south of the country (Jónasson 1945, 56). In most places the woodland diminished rapidly after the arrival of humans, presumably as a result of its over-exploitation for charcoal-making (associated with iron production and smithing) and for fuel, and as a result of rooting by pigs and grazing by sheep and goats (Hallsdóttir 1987; Eysteinsson and Blöndal 2003). This was also the case in the vicinity of Reykholt, where a decline in birch pollen occurs almost immediately above the landnám tephra, declining even more rapidly from c. AD 1150 until c. AD 1300 (Erlendsson pers comm). The absence of charred birch in the barley sample from the fireplace may be an indication of its diminishing supply. There is evidence of iron smelting at Reykholt (Thilo Rehren pers comm) in a smithy dated to between the 11th and 13th centuries AD (Table 1). There is further evidence of both smelting and charcoal production at Háls further up the valley (Smith 2005), an area where woodland was maintained somewhat longer than close to Reykholt.

\section{The medieval layers: summary}

Micromorphological analysis revealed in situ clay floor layers in the western end of structure 10/11, which were not identified during excavation, suggesting a small well-maintained room attached to the underground passage. They contained small fragments of fishbone and mammal bones, but no remains of plants or insects.

The midden-like deposit [577] outside the entrance to structure 12 contained hearth waste and floor deposits, cleared by repeated dumping from human quarters. There was evidence of the use of barley and oats, either locally grown or imported, and of other plants that may have been consumed or used for medical purposes. Cattle, sheep, goat, fish and seal were eaten on site, and the fish recovered had been processed before it was transported inland.

Like in the post-medieval period, the ground in the immediate vicinity of the site was dry with sparse vegetation, and the wider environment consisted of dry meadow and pasture communities.

\section{Conclusions}

Radiocarbon dating, and artefactual and written evidence, has dated the occupation of the farm mound to between the 10th and early 19th centuries AD. Assuming the earliest dates reflect the earliest occupation, the site would belong to the second generation of settlements in the area. The first half of the 13th century, when the chieftain Snorri Sturluson resided at Reykholt and enriched the farm with great wealth and power, is of special historical interest. For the first time in Iceland attempts are made to seek explanations for increased wealth in the environmental record.

The palimpsest of building activity which created the farm mound at Reykholt led to the destruction of many underlying layers and only some of the occupation phases were available for detailed study. The discussion therefore centres on two relatively well preserved phases, the earliest and the latest occupation layers. A direct comparison between the results of the analyses is not possible since the same kinds of deposits were not available for study and the taphonomy differed between the phases.

During the initial occupation phase barley seems to have been grown locally. Cereal was only grown in a few places in Iceland at that time and these are likely to have been the higher status farms. There is no apparent link at Reykholt between the growing of cereals and climate, indicating that the decision to grow barley rested on other factors, such as labour availability, soil fertility and the price of imported cereal.

Observations on thin sections from midden [577] give some information about fuel resources. There appears to have been no shortage of peat, which may have been brought from some distance to the site. The peat largely appears in the midden as fuel residue, which may explain, in part at least, the apparent contrast with the palynological results which may derive from local vegetation. The typically heterogeneous nature of midden deposits and any imprecision in correlating sampling locations within 
the midden, will have compounded any sampling errors. The decline in wood, also evident in the pollen record between the mid-12th century and $c$. AD 1300, may have led to an increased use of animal manure as fuel. It is tempting to link the deterioration in the local birch with increased activity at the site during its height in wealth and power. It does not appear to be linked to climatic deterioration.

During both the early and late medieval periods there is evidence of processed marine fish, seal and use of seaweed at the site, indicating that Reykholt was part of a regional trade network, and this was also apparent in the post-medieval farm. The import of wood, glass, ceramics and perhaps cereals in all periods shows that the farm was also part of a longdistance trade network. Together with evidence of the collection of driftwood, only available to higher status farms, these are further signs of its wealth.

The palaeoecological work has given valuable insights into the ecology and environment of the site at specific times during its occupation and aided archaeological interpretation. The project has invited specialists in different disciplines to integrate their work, but also highlighted the limitations of such work because of differing taphonomy and preservation. Although this work has only produced indirect evidence for changes in the fortune of the farm over time, this, coupled with the discovery of impressive structural remains, leaves us in no doubt of its high status in the medieval period.

\section{Acknowledgements}

Much of the environmental research presented in this paper was financed by The Leverhulme Trust as part of the Landscapes circum-Landnám project. The excavations of the farm site at Reykholt were financed by a special grant given by the Icelandic Government to the National Museum of Iceland. The Icelandic Research Fund for Graduate Students is thanked for support. Paul C. Buckland assisted with the identification of the insects and Jennifer Brown is thanked for producing Fig. 1.

\section{References}

Adderley, W. P., Simpson, I. A. and Davidson, D. A. 2006. Historic landscape management: a validation of quantitative soil thin section analyses. Journal of Archaeological Science 33, 320 34.

Ágústsson, H. 1987. Íslenski torfbærinn (The Icelandic turf-built farmhouse), pp. 229-344 in Jóhannsson, F. F. (ed.), Íslensk pjóðmenning 1 (Icelandic National Culture 1). Reykjavík: Bókaútgáfan bjóðsaga,

Amorosi, T., Buckland, P. C., Ólafsson, G., Sadler J. P. and Skidmore, P. 1992. Site status and the palaeoecological record: a discussion of results from Bessastaðir, Iceland, pp. 169-92 in
Morris, C. D. and Rackham, D. J. (eds.), Norse and Later Settlement and Subsistence in the North Atlantic. Glasgow: Dept of Archaeology, University of Glasgow.

Amundsen, C., Perdikaris, S., McGovern, T. H., Krivogorskaya, Y., Brown, M., Smiarowski, K., Storm, S., Modugno, S., Frik, M. and Koczela, M. 2005. Fishing booths and fishing strategies in Medieval Iceland: an archaeofauna from the midden of Akurvík, North-West Iceland, Environmental Archaeology 10 (2), 121-44.

Andersen, S. T. 1979. Identification of wild grass and cereal pollen. Danmarks Geologiske Undersogelse Arbok 1978, 69-92.

Benediktsson, J. (ed.) 1968. Íslendingabók. Landnámabók (Book of Icelanders, Book of Settlements). Íslenzk fornrit 1. Reykjavík: Hið íslenzka fornritafélag.

Bronk Ramsey, C. 2006. OxCal v. 3·10. http://www.rlaha.ox.ac.uk/ oxcal/oxcal.htm

Buckland, P. C. 2005. Insect faunas from Context 577, Reykholt. Unpublished report for the National Museum of Iceland.

Buckland, P. C. and Perry, D. W. 1989. Ectoparasites of sheep from Stóraborg, Iceland and their interpretation. Piss, parasites and people, a palaeoecological perspective. Hikuin 15, 37-46.

Buckland, P. C., Sadler, J. and Sveinbjarnardóttir, G. 1992. Palaeoecological investigations at Reykholt, Western Iceland, pp. 149-68 in Morris, C. D. and Rackham, D. J. (eds.), Norse and Later Settlement and Subsistence in the North Atlantic. Glasgow: Dept of Archaeology, University of Glasgow.

Buckland, P. C., Sadler, J. P. and Smith, D. 1993. An insect's eye-view of the Norse farm, pp. 518-28 in Batey, C. E., Jesch, J. and Morris, C. D. (eds.), The Viking Age in Caithness, Orkney and the North Atlantic. Edinburgh: Edinburgh University Press.

Buckland, P. C., McGovern, T. H., Sadler, J. P. and Skidmore, P. 1994. Twig layers, floors and middens. Recent palaeoecological research in the Western Settlement, Greenland, pp. 132-43 in Ambrosiani, B. and Clarke, H. (eds.), Developments Around the Baltic and the North Sea in the Viking Age (Birka Studies 3). Stockholm. Birka Project.

Bullock, P., Fedoroff, N., Jongerius, A., Stoops, G., Tursina, T. and Babel, U. (1985) Handbook for Soil Thin Section Description. Waine Research, Wolverhampton.

Canti, M. G. 1997. An investigation of microscopic calcareous spherulites from herbivore dungs. Journal of Archaeological Science 24, 219-31.

Caseldine, C. 2001. Changes in Betula in the Holocene record from Iceland - a palaeoclimatic record or evidence for early Holocene hybridisation? Review of Palaeobotany and Palynology 117, 13952.

Clark, R. L. 1982. Point-count estimation of charcoal in pollen preparations and thin sections of sediments. Pollen et Spores 24, 523-35.

Coope, G. R. and Osborne, P. J. 1968. Report on the Coleopterous fauna of the Roman well at Barnsley Park, Gloucestershire. Transactions of the Bristol and Gloucestershire Archaeological Society, 86, 84-7.

DI I = Jón Sigurðsson (ed.) 1857-76. Diplomatarium Islandicum, 8341264, Íslenzkt fornbréfasafn, 1. Copenhagen: S. L. Möller.

Edvardsson, R. and McGovern, T. H. 2005. Archaeological excavations at Vatnsfjörður 2003-04. Archaeologica Islandica 4, 16-31.

Eggertsson, Ó. 1993. Origin of the driftwood on the coasts of Iceland, a dendrochronological study. Jökull 43, 15-32.

Einarsson, D. 1963. Vitnisburður frjógreiningar um gróður, veðurfar og landnám á Íslandi (Pollen evidence for vegetation, climate and settlement in Iceland). Saga 1962, 442-69.

Einarsson, O. 1971. Íslandslýsing (Description of Iceland). Reykjavík: Bókaútgáfa Menningarsjóðs.

Erlendsson, E., Edwards, K. J., Lawson, I. T. and Vésteinsson, O. 2006. Can there be a correspondence between Icelandic palynological and settlement evidence, pp. 345-51. in Arneborg, J. and Grønnow, B. (eds.), The Dynamics of Northern Societies (Proceedings of the SILA/NABO 2004 Conference). Copenhagen: Publications from the National Museum Studies in Archaeology and History Vol. 10.

Erlendsson, E. 2007. Environmental Change Around the Time of the Norse Settlement of Iceland. Unpublished Ph.D. thesis. Aberdeen University. 
Eysteinsson, D. and Blöndal, S. 2003. The forests of Iceland at the time of settlement: their utilisation and eventual fate, pp. 411-15 in Lewis-Simpson, S. (ed.), Vinland Revisited: The Norse World at the Turn of the 1st Millennium. St Johns: Historic Sites Association of Newfoundland and Labrador Inc.

Faegri, K. and Iversen, J. 1989. Textbook of Pollen Analysis, 4th edn, revised by Faegri, K., Kaland, P. E. and Krzywinski, K. New York: John Wiley and Sons.

Grímsdóttir, G. Á. and Ingimundardóttir, B. (eds.) 2005. Mýra- og Borgarfjarðarsýslur. Sýslu- og sóknarlýsingar Hins islenska bókmenntafélags 1839-1873 (Mýra- and Borgarfjordur District. District and Parish Descriptions by The Icelandic Literary Association 1839-1873). Reykjavík: Sögufélag, Örnefnastofnun Íslands.

Grönvold, K., Óskarsson, N., Johnsen, S. J., Clausen, H. B., Hammer, C. U., Bond, G. and Bard, E. 1995. Ash layers from Iceland in the Greenland GRIP ice core correlated with oceanic and land sediments. Earth and Planetary Science Letters 135, 149-55.

Guðmundsson, G. 2002. Reykholt 2000. Assessment of preservation and potential of plant remains from context 577. Unpublished Fornleifastofnun Íslands report. FS 186-01211. Reykjavík.

Halldórsson, O. 1989. Skrifaðar bækur (Written books), pp. 57-89 in Jóhannsson, F. F. (ed.) Íslensk pjóðmenning 6 (Icelandic National Culture 6). Reykjavík: Bókaútgáfan pjóðsaga.

Hallsdóttir, M. 1982. Frjógreining tveggja jarðvegssniða úr Hrafnkelsdal. Áhrif ábúðar á gróðurfar dalsins (Two pollen diagrams from Hrafnkelsdalur. The effect of settlement on the vegetation in the valley). Árbók Hins íslenska Fornleifafélags 1982 , 253-65.

Hallsdóttir, M. 1987. Pollen Analytical Studies of Human Influence on Vegetation in Relation to the Landnám Tephra Layer in Southwest Iceland (Lundqua Thesis 18). Lund: Lund University.

Heiri, O., Lotter, A. F. and Lemcke, G. 2001. Loss on ignition as a method for estimating organic and carbonate content in sediments: reproducibility and comparability of results. Journal of Paleolimnology 25, 101-10.

Henderson, E. 1818. Iceland; or the Journal of a Residence in that Island during the Years 1814 and 1815. Edinburgh: Oliphant, Waugh and Innes.

Hillman, G. 1991. Charred remains of grains and seeds from the site Reykholt in Iceland. Unpublished report for Guðrún Sveinbjarnardóttir.

Jarðabók Árna Magnússonar og Páls Vidalín 4 (The Land Survey of Árni Magnússon and Páll Vídalín). Kaupmannahöfn 1925 and 1927: S. L. Möller.

Jóhannesson, J., Finnbogason, M. and Eldjárn, K. (eds.) 1946. Sturlunga saga Vol. I. Reykjavík: Sturlunguútgáfan.

Jónasson, J. 1945. Íslenzkir pjóðhattir (Icelandic Folk Customs). Reykjavík: Jónas og Halldór Rafnar.

Kenward, H. K. 1975. The biological and archaeological implications of the beetle Aglenus brunneus (Gyllenhall) in ancient faunas. Journal of Archaeological Science 2, 63-9.

Kenward, H. K. 1976. Further archaeological records of Aglenus brunneus (Gyll.) in Britain and Ireland, including confirmation of its presence in the Roman Period. Journal of Archaeological Science 3, 275-77

Kristjánsson, L. 1980. Íslenzkir sjávarhattir 1 (Icelandic Marine Customs and Practices). Reykjavík: Bókaútgáfa menningarsjóðs.

Krivogorskaya Y., Perdikaris, S. and McGovern, T. H. 2005. Fish bones and fishermen: the potential of zooarchaeology in the Westfjords. Archaeologica Islandica 4, 31-51.

Larsson, S. J. and Gígja, G. 1959. Coleoptera. Zoology of Iceland 43a. Copenhagen: Munksgaard.

Lindroth, C. H., Andersson, H., Bodvarsson, H. and Richter, S. H. 1973. Surtsey, Iceland. The Development of a New Fauna, 19631970. Terrestrial Invertebrates (Entomologica Scandinavica Supplement 5). Copenhagen: Munksgaard.

Lucht, W. H. 1987. Die Käfer Mitteleuropas, Katalog. Krefeld: Goecke and Evers

Milek, K. B. 2006. Micromorphological analysis of sediments in the medieval cellar, Structure 10, Area V, Reykholt. Unpublished report for Guðrún Sveinbjarnardóttir

Murphy, C. P. 1986. Thin Section Preparation of Soils and Sediments Berkhampstead: AB Academic Publishers.

Moore, P. D., Webb, J. A. and Collinson, M. E. 1991. Pollen Analysis, 2nd edn. Oxford: Blackwell Science.
Olsson, I. U. and Vilmundardóttir, E. 2000. Landnám Íslands og C-14 aldursgreiningar (The settlement of Iceland and ${ }^{14} \mathrm{C}$ dating). Skirnir vor 2000, 119-49.

Perry, D. W., Buckland, P. C. and Snæsdóttir, M. 1985. The application of numerical techniques to insect assemblages from the site of Stóraborg, Iceland. Journal of Archaeological Science 12, 335-45

Simpson, I. A., Vésteinsson, O., Adderley, W. P. and McGovern, T. H. 2003. Fuel resources in landscapes of settlement. Journal of Archaeological Science 30, 1401-20.

Smith, D. N. 1998. Beyond the barn beetles: difficulties in using Coleoptera as indicators of stored fodder. Environmental Archaeology 1, 63-70.

Smith, K. P. 2005. Ore, fire, hammer, sickle: iron production in Viking Age and Early Medieval Iceland, pp. 183-206 in Bjork, R. H. (ed.) De Re Metallica: The use of Metal in the Middle Ages (AVISTA Studies in the History of Medieval Technology, Science and Art, Vol. 4). Aldershot: Ashgate Publishing Ltd.

Stockmarr, J. 1971. Tablets with spores used in absolute pollen analysis. Pollen et Spores 13, 614-21.

Stoops, G. 2003. Guidelines for the Analysis and Description of Soil and Regolith Thin Sections. Madison: Soil Science Society of America.

Steindórsson, S. 1964. Gróður á Íslandi (Vegetation in Iceland). Reykjavík: Almenna bókafélagið.

Steindórsson, S. 1981. Flokkun gróðurs í gróðurfélög (Classification of vegetation into vegetation communities). Journal of Agricultural Research in Iceland 12, 11-52.

Sveinbjarnardóttir, G. 1996. Leirker á Íslandi - Pottery Found in Excavations in Iceland (Rit Hins Íslenska Fornleifafélags og pjóðminjasafns Íslands 3). Reykjavík: Háskólaútgáfan (University of Iceland Press).

Sveinbjarnardóttir, G. 2001. Reykholti i Borgarfirði. Framvinduskýrsla 2000 (Reykholt in Borgarfjordur. Progress Report 2000) (Rannsóknarskýrslur fornleifadeildar bjóðminjasafns 2000, 4). Reykjavík: National Museum of Iceland.

Sveinbjarnardóttir, G. 2003. Reykholti i Borgarfirði. Framvinduskýrsla 2002 (Reykholt in Borgarfjordur. Progress Report 2002) (Rannsóknarskýrslur fornleifadeildar bjóðminjasafns 2002, 3). Reykjavík: National Museum of Iceland.

Sveinbjarnardóttir, G. 2004. Interdisciplinary research at Reykholt in Borgarfjörður, pp. 93-7 in Guðmundsson, G. (ed), Current Issues in Nordic Archaeology (Proceedings of the 21st Conference of Nordic Archaeologists, 6-9 September 2001, Akureyri, Iceland). Reykjavík: Society of Icelandic Archaeologists.

Sveinbjarnardóttir, G. 2005. The use of geothermal resources at Reykholt in Borgarfjörður in the medieval period: some preliminary results, pp. 208-16 in Mortensen, A. and Arge, S. V. (eds.), Viking and Norse North Atlantic. Select Papers from the Proceedings of the Fourteenth Viking Congress, Tórshavn, 19-30 July 2001 (Annales Societatis Scientiarum Færoensis. Supplementum XLIV). Tórshavn: The Faroese Academy of Sciences.

Sveinbjarnardóttir, G. 2006. Reykholt: a centre of power: the archaeological evidence, pp. 25-42 in Mundal, E. (ed.), Reykholt Som Makt- og Lardomssenter i den Islandske og Nordiske Kontekst (Reykholt as a Centre of Power and Learning in an Icelandic and Nordic Context). Reykholt: Snorrastofa

Sveinbjarnardóttir, G. in press. The making of a centre: the case of Reykholt, Iceland, in Sheehan, J., O Corrain, D. and Wallace, P. F. (eds.), The Viking Age: Ireland and the West (Proceedings of the XVth Viking Congress, Cork, 2005). Dublin: Four Courts Press.

Sveinbjörnsdóttir, A., Heinemeier, J., and Guðmundsson, G. 2004. $14 \mathrm{C}$ dating of the settlement of Iceland. Radiocarbon 46(1), 38794

Tweddle, J. C., Edwards, K. J. and Fieller, N. R. J. 2005. Multivariate statistical and other approaches for the separation of cereal from wild Poaceae pollen using a large Holocene dataset. Vegetation History and Archaeobotany 14, 15-30.

Vickers, K. 2006. The Palaeoentomology of the North Atlantic Islands. Unpublished Ph.D. thesis, University of Sheffield.

Vigfússon, S. 1885. Rannsókn í Borgarfirði 1884 (Investigations in Borgarfjordur in 1884). Árbók Hins islenska fornleilafélags 1884-5, $61-138$ 
Zutter, C. 2000 . Wood and plant use in 17 th-19th century Iceland: archaeobotanical analysis of Reykholt. Environmental Archaeology 5, 73-82.
Dórarinsson, D. 1974. pjóðin lifði en skógurinn dó (The people lived but the woods died). Ársrit skógraktarfélags Íslands 1974, $16-29$. 